\title{
Importance of Estrogenic Signaling and Its Mediated Receptors in Prostate Cancer
}

\author{
Kin-Mang Lau * and Ka-Fai To * \\ Department of Anatomical and Cellular Pathology, State Key Laboratory of Oncology in Southern China, \\ and Sir YK Pao Centre for Cancer, The Chinese University of Hong Kong, Hong Kong, China \\ * Correspondence: kmlau@cuhk.edu.hk (K.-M.L.); kfto@cuhk.edu.hk (K.-F.T.); \\ Tel.: +852-2632-2350 (K.-M.L.); +852-2632-3335 (K.-F.T.)
}

Academic Editor: William Chi-shing Cho

Received: 25 July 2016; Accepted: 23 August 2016; Published: 31 August 2016

\begin{abstract}
Prostate cancer (PCa) treatment was first established by Huggins and Hodges in 1941, primarily described as androgen deprivation via interference of testicular androgen production. The disease remains incurable with relapse of hormone-refractory cancer after treatments. Epidemiological and clinical studies disclosed the importance of estrogens in PCa. Discovery of estrogen receptor $E R \beta$ prompted direct estrogenic actions, in conjunction with $E R \alpha$, on PCa cells. Mechanistically, ERs upon ligand binding transactivate target genes at consensus genomic sites via interactions with various transcriptional co-regulators to mold estrogenic signaling. With animal models, Noble revealed estrogen dependencies of PCa, providing insight into potential uses of antiestrogens in the treatment. Subsequently, various clinical trials were conducted and molecular and functional consequences of antiestrogen treatment in PCa were delineated. Besides, estrogens can also trigger rapid non-genomic signaling responses initiated at the plasma membrane, at least partially via an orphan G-protein-coupled receptor GPR30. Activation of GPR30 significantly inhibited in vitro and in vivo PCa cell growth and the underlying mechanism was elucidated. Currently, molecular networks of estrogenic and antiestrogenic signaling via ER $\alpha, E R \beta$ and GPR30 in PCa have not been fully deciphered. This crucial information could be beneficial to further developments of effective estrogen- and antiestrogen-based therapy for PCa patients.
\end{abstract}

Keywords: prostate cancer; estrogens; antiestrogens; estrogen receptors; ER $\alpha$; ER $\beta$; GPR30; GPER; fulvestrant

\section{Prostate Cancer Epidemiology}

Prostate cancer (PCa) is the most common solid malignancy and the second leading cause of cancer-related death in men in the United States, posing significant impacts on men's health. The American Cancer Society estimates for 2016 that approximately 180,890 new cases will be diagnosed and 26,120 men will die of the disease, accounting for about $8.3 \%$ of male cancer-related deaths (American Cancer Society, Cancer Statistics Center [1]). This cancer is extremely rare before the age of 40 but the incidence increases with age. The rate of increase with age is higher than those for any other cancers and it increases at approximately the 9th-10th power of age [2]. In addition, race is also an important risk factor. African-American men have the highest rates in the world at about 50\%-70\% higher than in Caucasian-Americans [3-11]. For Asian populations, native Chinese and Japanese have the lowest PCa rates $[4,8,12,13]$. The differences in the incidences was supposed to be related to different detection strategies for PCa. However, after adjusting these diagnostic biases, there are still significant differences among populations $[8,12,14]$. Even though the incidence rates of Chinese- and Japanese-Americans increase after they emigrated to America as compared to those in 
their homeland, the rates are still much lower than that of Caucasians and African-Americans [14-17], indicating the importance of intrinsic contributing factors to this disease.

Regardless of the incidence rates of symptomatic $\mathrm{PCa}$, there are no significant differences for microscopic cancers (i.e., latent cancers) among races [18-21]. These asymptomatic cancers were frequently found in elderly men either at autopsy or after cryoprostatectomy for various pathological conditions of their bladders. It is usually small, with a $<0.5 \mathrm{~mm}$ diameter, and well differentiated [20,22-24]. Similar prevalence of this latent cancer among racial groups suggests that PCa initiation is likely due to endogenous factors, although the promotion step leading to clinical symptomatic cancer is predominantly influenced by exogenous factors [25]. It was speculated that endogenous estrogens such as estrone and estradiol and exogenous estrogens, e.g., phytoestrogens and xenoestrogens, dictate the estrogenic signaling in the prostate to modulate the promotion step for clinical cancer developments [25].

\section{Epidemiological and Clinical Evidence of Hormonal Involvements in Prostatic Carcinogenesis}

Epidemiological studies of hormone profiles of populations with different degrees of PCa risk demonstrated that high serum levels of estrogens were associated with high risk and thus this steroid hormone might be one of the risk factors [3,26-29]. It was reported that the levels of estrone and estradiol in African old men are higher than those in Caucasian [26,30-32]. In addition, serum levels of estradiol were $15 \%$ higher in Caucasian-Dutch men than in Japanese men [28]. Regarding prenatal exposures, pregnant African-American women have 37\% higher circulating estradiol levels than European-American women, indicating higher exposure to estrogens in African-American men than European-American before birth [27,29]. However, population-based case-control studies [33-37] generally showed no significant differences in serum levels of estrogens between cancer patients and control subjects, except Barrett-Connor et al.'s study that the incidence rate linearly increased with increasing serum level of estradiol [38].

Furthermore, the incidence of PCa sharply increases in aging men at a time when the ratio of estrogens to androgens showed a $40 \%$ increase. As men age, their plasma levels of testosterone and other androgenic hormones decrease due to declining testicular functions [25,39-43]. Concurrently, the prostatic epithelial cells but not stromal cells have lower levels of $5 \alpha$-hydrotestosterone (DHT) [44] although the level in the whole prostate showed no change [45] in accordance with the previous findings of the decreased DHT-forming index (i.e., $V_{\max } / K_{\mathrm{m}}$ of $5 \alpha$-reductase) with age [46]. Concurrently, serum estrogens in aging men increase because of active aromatization of adrenal androgens to estrogens in their peripheral adipose tissues [25,39-42,47]. These endocrine changes at men's mid-life are referred as an andropause. Besides, high cellular levels of estrone and estradiol are observed in the aged prostate [44]. Taken all together, the changes of hormonal stimulations in the aged prostate, especially increased estrogenic stimulation, may contribute to prostatic carcinogenesis.

\section{Estrogen- and Androgen-Induced Prostatic Lesions in Animals}

Administration of pharmacological doses of estrogens had been reported to induce squamous metaplasia (i.e., a proliferative activity of basal cells with transdifferentiation into any intermediate stage of differentiation between squamous cells, luminal secretory cells and basal cells in epithelium) in regressed prostates of castrated or hypophysectomized dogs [48,49]. Levine and colleagues also observed this estrogen-induced squamous metaplasia in men who had benign prostatic hyperplasia and underwent medical castration therapy with gonadotropin-releasing hormone agonist for more than six months [50]. The metaplastic change is initiated by proliferation of basal cells which subsequently differentiate into squamous cells [48-50]. On the contrary, administration of estrogen in castrated guinea pigs induced hypertrophy of secretory cells in the lateral prostate and increased the thickness of fibromuscular layer, possibly due to the increased cell proliferation of smooth muscle cells [51-54]. Different from dogs, only the seminal vesicle showed basal cell hyperplasia in the estrogen-treated castrated guinea pigs $[52,53]$. For the intact mice, a synthetic estrogen diethylstilbestrol provoked 
epithelial squamous metaplasia in the prostate [55]. These indicated that hormonal backgrounds, likely androgenic stimulations in the intact animals, are crucial in directing the cell fate of estrogenic responses in the prostate.

When Wistar rats were prenatally and/or neonatally exposed to estrogens, they developed squamous cell carcinoma in the prostate [56-59]. Prenatal [59] and neonatal [60] estrogenic exposures induced hyperplasia and dysplasia in the prostates respectively. It was reported that increase of free-serum estradiol in male murine fetuses though a maternal Silastic estradiol implant induced prostate enlargement in the adult mice with increased androgen sensitivity [61]. The sensitivity to androgens in the adult prostate was also enhanced by a low-dose treatment of estradiol in the immature male rat at 20-22 days of age. This permanent alteration of the prostate by neonatal estrogen treatment was described as "estrogen imprinting" [62]. Comprehensive studies of estrogen imprinting in rat prostates demonstrated a decrease in weight, alterations of DNA contents and morphological changes in three prostatic lobes (ventral, lateral and dorsal) of neonatal estrogenized rats $[63,64]$. The hypoplastic ventral and dorsal prostates showed an increase of interacinar stromal tissues, epithelial hyperplasia in disorganized acini, luminal sloughing and apparent lack of differentiation as well as a decrease in the levels of androgen and estrogen receptors [63-65].

Treatment of estradiol in intact Noble rats caused massive atrophy in the prostate [66,67]. This may be due to suppression of LHRH stimulation of the pituitary gland by the estrogens. The treatment indirectly decreases production of testicular testosterone. As the prostate largely depends on androgens for its normal growth and functions, reduction of androgen level results in the regression $[66,67]$. Combined treatment of testosterone and estradiol induced PCa in Noble rats after 32 weeks with $100 \%$ induction rate [66,68-72]. The cancers were derived from the periurethral, proximal ducts of the dorsolateral and anterior prostates of the rats $[66,67,72]$. The induction can also be achieved in a shorter period of time by an extremely high dose of testosterone in combination with estradiol [73]. In fact, long-term androgen, either testosterone or $5 \alpha$-dihydrotestosterone, treatment alone was able to induce PCa but the incidence was low $[66-69,74]$. Taken together, testosterone is likely a weak carcinogen but estradiol in combination can potentiate these carcinogenic effects in the prostate, implying the significance of estrogens in prostatic carcinogenesis. Interestingly, the estradiol plus testosterone treatment-induced PCa in Noble rats was confined to the periurethral, proximal ducts of the dorsolateral and anterior prostates but not in the periphery of the glands where dysplasia developed in the acini $[66,67,72]$. Histologically, the acinar dysplasia in the periphery of the rat prostate is similar to human prostatic intraepithelial neoplasia (PIN) which is considered to be a precursor of prostatic adenocarcinoma $[66,67,72,75-81]$. In addition to the Noble rats, the combined treatment induced atypical hyperplasia and carcinoma in a subset of mouse prostate tissues $[82,83]$. Furthermore, the importance of estrogens in prostate carcinogenesis was also demonstrated by administrations of testosterone and estradiol to aromatase knockout mice that prevent conversion of testosterone into estradiol [84]. The combined treatment induced PIN whereas no change was observed in the mice with androgen alone, highlighting the implications of local production of estrogens within the prostate in the carcinogenesis [84]. In fact, increased expression of aromatase was frequently found in human PCa $[85,86]$.

\section{Estrogen Receptors (ERs) and Estrogenic Actions in Normal Prostate}

It is widely believed that the actions of estrogens are mediated by ERs. Binding of estrogens leads to conformational changes of ER and then the complexes recruit transcriptional factors to form transcriptional machineries for gene expression. Next, the whole complexes bind to specific regulatory regions of DNA to stimulate transcription of estrogen-related genes such as progesterone receptor and pS2 $[87,88]$. Besides, ERs also regulate transcription through protein-protein interactions with other transcription factors such as AP-1 and Sp-1 to mold the transcriptional networks [89-91]. Ligand-binding studies demonstrated two estradiol-binding sites, including high-affinity (type I) and low-affinity (type II) sites, in the rat and human prostates. The type I-binding site usually refers to 
classical estrogen receptor $(E R \alpha)$ while the type II-binding site is still poorly characterized [92-95]. The combined treatment of testosterone and estradiol in Noble rats elevated the level of type II-binding site in the prostate along with an increase in wet weight of the glands [67]. Inhibition of this type II-binding site with a specific antagonist, 2,6-bis((3-methoxy-4-hydroxyphenyl)-methylene)-cyclohexanone, in intact adult mice reduced prostatic weight in a dose-dependent manner [96]. Fluorographic studies with $\left[{ }^{3} \mathrm{H}\right]$-luteolin-labeled type II-binding site from rat uterine nuclear extracts identified a histone H3-H4 dimer likely responsible for the binding [97]. In addition, another estrogen receptor (ER $\beta$ ) was cloned in rat prostate [98] and later found in human testis [99]. However, this ER subtype shows high affinity to estrogens similar to ER $\alpha$. Taken together, the normal prostate contains at least two high-affinity estradiol-binding sites (ER $\alpha$ and $E R \beta)$ and one low-affinity (type II) site.

Prior to the discovery of ER $\beta$, immunohistochemical and in situ hybridization data demonstrated expression of ER $\alpha$ in the stroma of human prostate but not in epithelial cells [100-102]. During human fetal development, ER $\alpha$ is restricted to stromal cells [103]. Based on the cellular localization of ER $\alpha$, estrogens were speculated to bind the stromal cell receptors and exert its indirect effects on epithelium via paracrine mediators like stromal cell-growth factors [104-106] (Figure 1). This notion was supported by the findings that the level of stromal basic fibroblast growth factor (bFGF) increased in the prostates of estrogen-treated rats [107]. In addition, estrogens enhanced synthesis of epidermal growth factor (EGF) and insulin like growth factor-1 (IGF-1) via an ER-mediated pathway to excite prostatic enlargement as demonstrated in organ culture of rat fetal prostate [108]. In line with these observations, these growth factors can stimulate growth of prostatic epithelium $[109,110]$. Administration of EGF or bFGF orthotopically in ventral prostates of adult rats increased the prostate size with enhanced growth of prostatic epithelium [109]. Moreover, systemic administration of IGF-1 can induce growth of the rat prostate [111]. It was also demonstrated that IGF-1 stimulated proliferation of prostatic epithelial cells derived from monkey prostate on extracellular matrix substrates [110]. However, there was no marked phenotype in the prostate of ER $\alpha$ knockout mice, suggesting that ER $\alpha$ is dispensable for the normal growth and functions of the prostate and the other compensating receptors also mediate estrogenic actions of the gland $[112,113]$.

\section{Estrogenic actions in normal prostate}

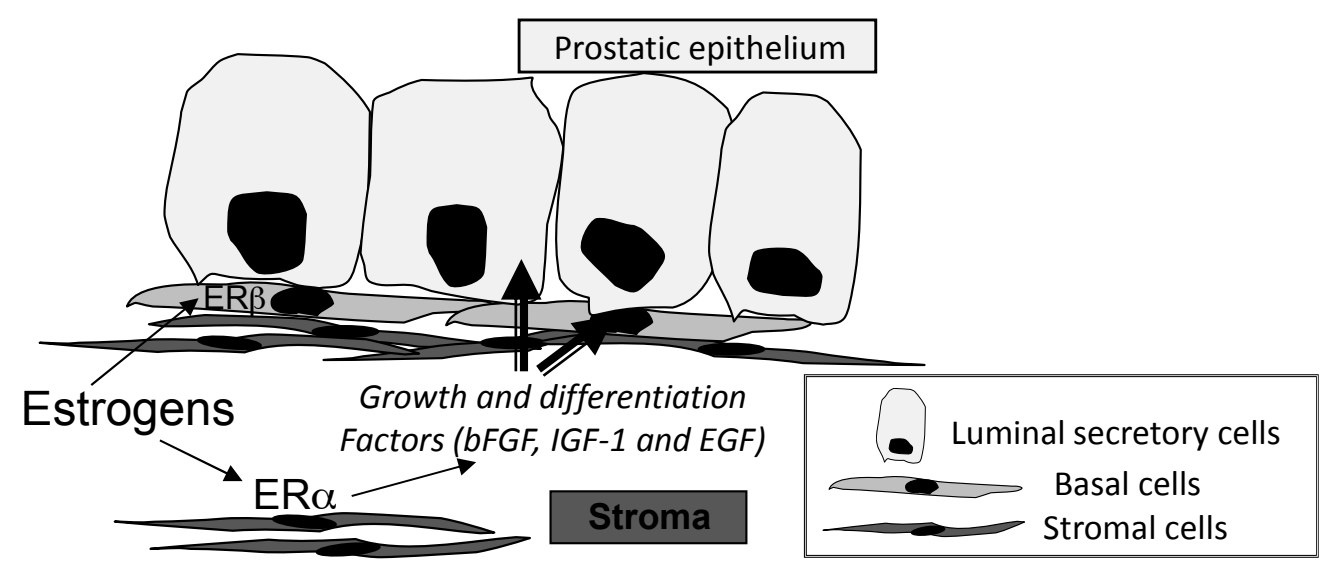

Figure 1. Estrogenic actions in normal prostate. Estrogens bind ER $\alpha$ in stromal cells to induce conformational changes of the receptor and the whole complexes stimulate the cells to express stromal cell growth and differentiation factors like basic fibroblast growth factor (bFGF), insulin like growth factor-1 (IGF-1) and epidermal growth factor (EGF) to regulate the growth and functions of prostatic epithelial cells in a paracrine action between stromal and epithelial cells. In addition, estrogens also exert direct effects on prostatic basal cells via interactions with ER $\beta$ to mold the estrogenic signals in the prostate. 
Discovery of ER $\beta$ in prostatic epithelial cells weakens the notion of sole paracrine estrogenic effects of stromal cells on prostatic epithelium. Estrogens also exert direct effects on epithelium of the prostate via ER $\beta$. Previously, expression and cellular localization of the two ERs had been studied in normal human prostate but the results remained inconclusive. Bohkhoff and colleagues found that $E R \alpha$ expression was restricted to stromal and basal cells and the receptor was undetectable in secretory luminal epithelial cells. Also, none of stromal and epithelial compartments expressed ER $\beta$ [114]. In contrast, we [115] and others [116] demonstrated presence of ER $\beta$ only in basal epithelial cells, whereas ER $\alpha$ was predominantly expressed in stromal cells of normal human prostate (Figure 1).

Histologically, human prostate is comprised of peripheral, transitional and central zones and they have different hormone receptor profiles determined by ligand-binding assays [117-119]. High ratio of androgen receptor (AR) to progesterone receptor was found in transitional and central zones as compared to that in peripheral zone of the human prostate [117]. Uneven distribution of AR was also observed in normal human prostate, showing higher levels in the peripheral zone than those in the other zones [118]. Additionally, the transitional zone contains higher levels of EGF and bFGF as well as androgens than peripheral zones [120]. Different zones of the prostate showed differences in their tissue architectures, cellular morphology and hormone receptors profiles. The majority of prostate cancers are derived from the peripheral zone where PIN lesions are frequently found while benign hyperplasia frequently develops in the transitional zone. The central zone is rarely the site of PCa origin [121]. In the peripheral zone, basal and secretory cells in low- to moderate-grade dysplastic lesions expressed nuclear ER $\beta$ but the expression diminished in the dysplastic cells in the high-grade lesions [115]. No ER $\alpha$-positive dysplastic cells were found in the peripheral zone of the prostate. In contrast, some dysplastic cells in the central zone showed ER $\alpha$ expression [115], possibly implying the biological differences and distinct pathways of hormone responsiveness between these two zones of the prostate [115].

\section{Estrogen Receptor (ER) Expression and Estrogen Actions in PCa}

ER expression in human PCa is also controversial. By immunohistochemistry and in situ hybridization, no ER expression was detected in cancerous epithelial cells, and ER mRNA/proteinexpressing cells were limited to fibroblasts, myoblasts and smooth muscle cells of the tumor tissues [122-124]. On the contrary, Konishi et al. [100] detected a subset of ER-expressing PCa cells by immunohistochemistry. In addition, the results of RT-PCR demonstrated detectable levels of ER transcripts in two prostate cancer cell lines (PC-3 and LNCaP) that derived from PCa metastases $[125,126]$. Later, Bonkhoff et al. detected ER $\alpha$ but not ER $\beta$ transcripts in $11 \%$ of high-grade prostatic intraepithelial neoplasia, $43 \%$ of Gleason grade $4 \mathrm{PCa}$, and $61 \%$ of grade 5 cancer as well as $94 \%$ of recurrent adenocarcinoma after hormonal therapy [114]. However, Royuela and colleagues [116] observed both ER $\alpha$ and ER $\beta$ in epithelial compartment of the cancer. The stromal cells expressed ER $\alpha$ in the prostate but only a subset of PCa showed ER $\beta$ expression in their stromal compartments [116]. By RT-PCR of ER $\alpha$, three PCa cell lines (LNCaP, ARPCa and C4-2) expressed ER $\alpha$ mRNA as well as its splicing variants [127]. For the clinical specimens, Latil and colleagues [128] demonstrated detectable levels of ER $\alpha$ and ER $\beta$ transcripts in both normal and cancer tissues and they found downregulation of ER $\beta$ mRNA expression in one half of either localized or hormone-refractory tumors. By immunohistochemistry and RT-PCR on the micro-dissected samples, significant reduction of ER $\beta$ expression was indicated in grade $4 / 5$ carcinomas while the majority of grade 3 carcinomas expressed $E R \beta$ in the peripheral zone of the prostate [115]. In the extended cohort, ER $\beta$ expression was found in a few localized cancers and the expression was associated with poor relapse-free survivals [129]. In light of the findings of ER $\beta$ in sustaining E-cadherin expression and preventing an epithelial-mesenchymal transition (EMP) in PCa cells by sequestering Snail 1 in the cytoplasm [130], downregulation of this receptor expression in grade $4 / 5$ carcinomas provokes acquisition of mesenchymal characteristics and aggressive behaviors of the cells that are associated with high-grade PCa. 
Interestingly, the androgen-independent metastatic carcinoma cells in bone lesions and also nonosseous metastases regained ER $\beta$ expression, providing a critical foundation for developments of PCa therapy targeting this receptor for patients with relapses after androgen ablation therapy [115,131]. The mechanism underlying this regain remains unclear. As bone fibroblasts produced growth factors that, in turn, induced human PCa growth [132], it was speculated that the regain might be attributed to the unidentified stimulations of surrounding cells in the new tissue microenvironment of metastatic cells [115].

There are at least five splice variants of ER $\beta$ sharing the same first four functional domains but with different ligand-binding domains [133]. ER $\beta 3$ expression is restricted to testis whereas ER $\beta 1, E R \beta 2$, $E R \beta 4$, and ER $\beta 5$ are expressed in the prostate $[133,134]$. ER $\beta 2$ is the dominant isoform in PCa with no detectable affinity for estrogens and it is commonly localized in the cytoplasm, whereas the full-length ER $\beta 1$ is found in the nucleus [135]. It was demonstrated that ER $\beta 2$ functions as a transcriptional repressor of ER $\beta 1$ to negatively modulate ER $\beta 1$ activities [136]. Moreover, ER $\beta 2$ suppresses ER $\alpha$ signaling through proteasome-dependent degradation of ER $\alpha$ [137]. Besides cytoplasmic ER $\beta 2$, patients with biochemical relapse, postoperative metastases and shorter metastasis-free survivals frequently showed co-expression of nuclear ER $\beta 2$ and cytoplasmic ER $\beta 5$ in their tumors [135]. In line with this finding, ectopic expression of ER $\beta 2$ or ER $\beta 5$ in PCa cells enhanced their cell invasiveness, implying the metastasis-promoting roles of these two ER $\beta$ isoforms in PCa [135].

\section{Mechanistic Insights of ER $\beta$ - and ER $\alpha$-Mediated Signals}

The first human ER was cloned in 1986 [138,139]. A decade later, the second ER was identified by screening a rat prostate cDNA library using the PCR products generated from degenerate primers recognizing the conserved regions within the DNA- and ligand-binding domains of nuclear receptors [98,140]. The second ER was named as ER $\beta$ and the original ER as ER $\alpha$ [98]. Then, the sequences of $E R \beta$ in different species including human and mouse were subsequently cloned $[99,141]$. Comparison of the amino acid sequences of these two receptors in rat, mouse and human showed that ER $\beta$ is highly homologous to ER $\alpha$. They share $95 \%-97 \%$ homology in their DNA-binding domains and only $55 \%-60 \%$ in the ligand-binding domains. High variation was found in their N-terminal A/B domains with about $16 \%$ homology $[98,99,141]$. These differences likely result in differential cognate ligand profiles and transcriptional properties of these two receptors and elicit the uniqueness of each receptor in their biological functions.

Upon binding to ligands, ERs change their conformations and dimerize. The whole complex with other transcriptional factors interacts with specific DNA region as estrogen-responsive element (ERE) to regulate target gene expression. The ERE had been extensively studied in promoters of vitellogenin in Xenopus and chicken, and prolactin, progesterone receptor as well as pS2 in mammals. The consensus ERE consists of a 5 bp palindrome with a 3 bp spacer: GGTCAnnnTGACC [142]. By RT-PCR, tissue distribution of two receptors in rats had been investigated [143]. Kidney and adrenal gland predominantly or only express ER $\alpha$ transcripts while ER $\beta$ predominantly in lung, spinal cord and prostate. Both receptors are highly expressed in ovary and uterus [143]. In the $\mathrm{ER} \alpha$ - and ER $\beta$-coexpressing cells, the receptors predominantly form heterodimers upon binding to ligands as demonstrated by gel shift assays that two murine ERs dimerize with each other and bind to ERE [144]. The heterodimerization of human ER $\alpha$ and ER $\beta$ was also shown by mammalian two-hybrid assay and these physical interactions was verified by GST-pulldown and co-immunoprecipitation assays $[145,146]$.

At estrogen responsive element (ERE), ERs employ two transactivation functional domains (AF-1 and AF-2 in N-terminal domain (NTD) and ligand-binding domain (LBD) respectively) to recruit $\mathrm{p} 160$ coactivator proteins such as steroid receptor coactivator-1 (SRC-1), glutamate receptor interacting protein 1 (GRIP1) and nuclear receptor coactivator 3 (NCO3) $[147,148]$ that bind to an integrator molecule cyclic adenosine monophosphate response element-binding protein-binding protein $(\mathrm{CBP}) / \mathrm{p} 300$. Crystallographic studies indicated that nuclear receptor boxes of p160 bind 
to the hydrophobic cleft on the surface of LBD of ER $\alpha[148,149]$. Crystal structures of LBD of ER $\beta$ with ligands were similar to that of $\mathrm{ER} \alpha$ and it also forms a hydrophobic cleft for binding of $\mathrm{p} 160$ coactivators $[148,150]$. The orientations of helix 12 of both receptors dictate the activities of ligands, either agonistic or antagonistic, at ERE though modulating the binding of p160 coactivator [148-151]. In contrast to AF-2 in LBD, the activation of AF-1 in NTD of two receptors is ligand-independent and is triggered by phosphorylation [148,152-154]. The domain binds to C-terminus of p160 coactivators such as GRIP1 and synergizes with AF-2 for transcriptional regulation $[148,155]$.

In addition to ERE, ERs also regulate genes with promoters containing activation protein-1 (AP-1) sites $[88,148,156,157]$. The receptors, even without the DNA-binding domain (DBD), are able to transactivate ovalbumin gene promoter with AP-1 proteins like c-fos and c-jun proteins [156]. Similarly, IGF-1 expression is transcriptionally regulated by ER but there is no conventional ERE in the gene promoter [157]. ER facilitates binding of fos-jun protein complex onto the AP-1 site in this promoter for transactivation [157]. In collagenase gene promoter, tamoxifen- or estradiol-bound ER activated the promoter at the AP-1 site in both DBD-dependent and independent manners respectively $[88,147]$.

Estrogenic activation at the AP-1 site requires integrity of both AF-1 and AF-2 [147,148]. The LBD of ER $\alpha$ strongly activates AP-1 promoter in the presence of estrogens but not tamoxifen [147]. Deletion or mutation of AF-2 or AF-1 abolished or severely reduced this activation [147]. However, the role of DBD is not quite crucial [147]. These indicated that the estrogenic activation at the AP-1 site is AF-1/2-dependent and DBD-independent as well as ligand-specific (i.e., estrogen but not tamoxifen) $[147,156]$. In this signaling, the AP-1 site recruits fos-jun complex that stimulates transcription by interacting with $\mathrm{CBP} / \mathrm{p} 300$ and p160 coactivators. The estrogen-bound ERs trigger p160 in the pre-existing complex at the AP-1 site into a higher state of activity through both AF-1 and AF-2 of the receptors and then enhance CBP/p300 transcriptional activity [147].

On the contrary, tamoxifen-induced activation by ER at the AP-1 site was DBD-dependent and AF-independent [147,157]. Direct binding of ER onto the AP-1 site was not involved [157]. Deletion of DBD in ER abolished the promoter activation of IGF-1 [157]. ER $\beta$ bound with fulvestrant (ICI-182,780), raloxifene or tamoxifen but not estrogens can transactivate the promoter at the AP-1 site and the transactivation is completely independent of AF-2 [147,158]. ER $\alpha$ without AF-1 remained functional in this transactivation [147]. It indicated that AF-1 was dispensable in this DBD-dependent activation. As ER binds to a transcriptional corepressor N-CoR only in the presence of tamoxifen $[159,160]$, Kushner and his colleagues proposed the mechanism for this DBD-dependent and AF-independent activation of ER upon binding with tamoxifen at the AP-1 site [147]. The tamoxifen-bound ER at the site, where it is away from the AP- 1 site, binds to N-CoR and other corepressors and then the complex recruits histone deacetylases (HDACs), sequestering HDACs away from the AP-1 site. Eventually, the activity of histone acetylases in the fos-jun-p160-CBP/p300 complex is released, resulting in promoter transactivation $[147,148]$.

In addition, tamoxifen-bound ER can stimulate human quinone reductase (QR) gene expression via electrophilic responsive elements (EpRE) [161,162]. EpRE motif in human QR gene consists of 12-o-tetradecanoylphorbol-13-acetate (TPA) responsive element (TRE), TRE-like element and AP-1 site. The ER-mediated regulation of QR expression is independent of AP-1 proteins because TPA, a potent AP-1 activity inducer [163], alone cannot transactivate QR transcriptional activity [161,162]. Gel shift assay with rat glutathione-s-transferase-Ya EpRE, which has no AP-1 site, showed that the major EpRE-interacting and activating proteins are not AP-1 proteins (i.e., the fos-jun complex) [164,165]. At EpRE, ERs interact with hPMC2, human homolog of the Xenopus gene (XPMC2), that directly binds onto the site to recruit Nrf2 and PARP-1 coactivators for upregulation of QR expression $[166,167]$. ER $\beta$, rather than $\mathrm{ER} \alpha$, is the predominant interacting protein for hPMC2 [167]. Functionally, hPMC2 potentially acts as a negative cell cycle regulator through its regulation of $\mathrm{QR}$ transcriptional activity [166]. The enzyme activates the anticancer quinones which enhance cellular levels of reactive 
oxygen species (ROS) [168]. In turn, the increased ROS induced p21 expression to control cell cycle progression [168].

Interestingly, fulvestrant upregulated expression of interleukin-8 through NF- $\mathrm{kB}$ element of the promoter in a PCa cell line DU145 that predominantly expresses ER $\beta$ but no detectable ER $\alpha[169,170]$. Upon fulvestrant treatment, ER $\beta$ interacted with p65 targeting the NF- $\mathrm{KB}$ site to stimulate the expression. It implicated the roles of ER $\beta$ in modulating NF-KB-mediated pathways [171].

In summary, ERs upon ligand binding regulate expression of target genes through homoand/or hetero-dimerization and then directly binding onto ERE to transactivate the promoters or physically interacting with other transcriptional factors like AP-1, hPMC2 and NF-kB to recruit co-activators/co-repressors to mode the actions of estrogens and / or antiestrogens in a cell type-specific manner. Through these signaling actions, the endogenous and exogenous estrogens via ERs elicits their roles in controlling cell proliferation, apoptosis, migration and invasion capacities and communication networks with other cells. For instance, both AP-1 and hPMC2 are important in transcriptional regulation of p21 expression, in turn controlling the cell growth [156,168]. Also, regulation of hPMC2 expression by ERs in the cells modulates ROS levels in response to stress [166,167], and excess ROS can induce apoptosis. By interactions of $E R \beta$ with p65 targeting NF- $k B$ site [170], estrogenic signaling cross-talks with NF- $\mathrm{kB}$ pathway to control apoptosis and also cellular and tumor immunity. Any inappropriate stimulations of this signaling could tip the balance of these estrogenic signaling networks and then the related cellular processes, resulting in transformation into cancer/diseased cells.

\section{Biological Functions of ER $\alpha$ and ER $\beta$ Derived from Their Knockout Mice Models}

Precise disruption or knockout of a particular gene in animals and examination of their phenotypes can provide great insights into the roles of the gene in development and normal physiology. ER $\alpha[171,172]$ and ER $\beta[172,173]$ single knockout $(E R \alpha K O$ and $E R \beta K O)$ and double knockout $(E R \alpha \beta K O)[172,174]$ mice were generated and all of these $K O$ mice showed no lethality. Their phenotypes were distinct $[172,174,175]$. Males and females of ER $\alpha \mathrm{KO}$ and ER $\alpha \beta K O$ mice are infertile while only ER $\beta K O$ females are either infertile or subfertile with reduced litter size and the males are fertile [171-173]. In the female reproductive tract, ER $\alpha \mathrm{KO}$ mice develop hypoplastic uterus and vagina and there is no cyclic change [171]. However, the genital tract of ER $\beta K O$ is normal [173]. The lengths of oviduct, uterus horns and vagina of $E R \alpha \beta K O$ are normal while diameter and thickness are smaller than those in wild-type females [172,174]. Ovaries of ER $\alpha$ KO adults are anovulatory. They developed multiple hemorrhagic cysts and no corpora lutea. The ovaries underwent normal prenatal and neonatal developments [171,172]. Similar features of ovaries were found in $\mathrm{ER} \alpha \beta K \mathrm{KO}$ females. All ER $\alpha \beta K \mathrm{KO}$ ovaries contained fully differentiated Sertoli cells and exhibited follicle transdifferentiation to structures resembling seminiferous tubules of the testis [172,174]. They also showed increases of atretic follicles [173]. However, an independent study of ER $\alpha \beta K O$ mice found no such change and the ovaries were macroscopically normal [172]. In most of them, corpora lutea were scarce or absent [172]. These findings indicated that the roles of both ER $\alpha$ and ER $\beta$ in proliferation of granulosa cells are crucial and the presence of these two receptors are required to complete the folliculogenesis in ovary [172]. In the early stages of folliculogenesis, two ERs apparently are dispensable and can partially compensate each other in the inactivation of either of these two receptors. They showed some degrees of functional redundancy $[172,174]$.

In $E R \alpha K O$ and $E R \alpha \beta K O$ males, the testes lack germ cells in the seminiferous tubules and show a marked dilation of straight tubules and rete testis [141,174]. The male reproductive tracts of ER $\beta K O$ mice are normal, but the older animals develop hyperplasia in the prostate and the urinary bladder [173]. However, no such abnormalities were reported in a subsequent study and it even showed no change in cell proliferation in the prostates of 8- and 20-month-old ER $\alpha \beta K O$ mice with labeling indices by Ki67 and BrdU immunostainings [172]. Instead, the authors reported abundance-to-massive lymphoid aggregates associated with reactive epithelium in the prostates of 12-month-old ER $\beta K O$ mice and suggested the immunomodulatory roles of prostatic ER $\beta$ [176]. 


\section{Estrogen Therapy for Prostate Cancer}

Hormonal therapy is the mainstay of treatment in patients with metastatic PCa. Medical castration is commonly accomplished with luteinizing hormone-releasing hormone (LHRH) analogs. Diethylstibestrol (DES), a synthetic estrogen, is a good alternative for cost-effective therapy [177-181]. Theoretically, DES suppresses LHRH-induced stimulation of the pituitary gland and thus indirectly reduces production of testosterone in testis, resulting in decrease of serum testosterone to the anorchid level $[178,179,182]$. Subsequently, the androgen-dependent PCa regresses. Unfortunately, the disease eventually progresses into androgen-independent cancer that is irresponsive to this androgen ablation therapy. Emerging evidence indicated that DES did not suppress cancer growth solely through this pituitary-gonadal axis. Treatment of DES in the orchidectomized patients who already had very low levels of serum testosterone is still effective in suppression of PCa growth, suggesting that the inhibitory effects of DES are not only attributed to the reduced testosterone production. Several studies showed direct actions of DES on PCa cells [181,183-185]. Robertson et al. [185] demonstrated direct cytotoxic effects of DES on PCa cells via induction of apoptosis while Hartley-Asp et al. [184] indicated DES-induced metaphase arrest and inhibition of microtubule assembly in the cells. In addition, in vitro studies highlighted the involvements of ER in the estrogen-induced inhibition of PCa cell growth $[125,126]$. In contrast, estrogens, especially $17 \beta$-estradiol $\left(\mathrm{E}_{2}\right)$, stimulated proliferation of androgen-responsive PCa LNCaP cells, possibly related to the mutated androgen receptor with threonine to alanine at codon 868 which has high affinity to estrogens [186,187]. However, presence of ER by immunohistochemistry and RT-PCR analysis and blockade of $E_{2}$-induced growth by antiestrogen in LNCaP cells suggested the biological responses of LNCaP cells to $\mathrm{E}_{2}$ is likely mediated via ER [126]. For the androgen-irresponsive PCa cells (PC-3 and DU145), $\mathrm{E}_{2}$ inhibited the cell growth through an ER-associated pathway [125,169].

\section{Potential of Antiestrogens for PCa Therapy}

In the early 1980s, Noble [188] demonstrated the estrogen-dependence of PCa in Noble rat model. Removal of estrogen treatment and also blockade of estrogenic actions by a non-steroidal antiestrogen tamoxifen with continued estrogen treatment inhibited the tumor growth. These findings prompted the potential uses of antiestrogens as therapeutic agents for PCa [188]. Subsequently, various clinical trials were conducted to evaluate the efficacy of tamoxifen on patients with advanced PCa $[189,190]$. They demonstrated tamoxifen to be a palliative therapeutic agent for the disease, partially due to its estrogenic properties [191-193]. In the Eastern Cooperative Oncology Group trial, no patient responded to the treatment [194]. Moreover, the estrogenicity of tamoxifen posed increased risks of cardiovascular disease similar to the side effects of DES treatment. Therefore, evaluations of the potential uses of antiestrogens as therapeutic agents in a single-arm or adjuvant treatment for PCa patients were discontinued. It was not until later that two steroid antiestrogens, ICI-164,384 and ICI-182,780 (fulvestrant), were developed with no estrogenic activity, different from tamoxifen [195,196]. The therapeutic potential of these antiestrogens for PCa were revisited and preclinical studies demonstrated anti-proliferative effects of fulvestrant on androgen-responsive and -irresponsive PCa cells (LNCaP, DU145 and PC-3) [169,197]. Fulvestrant inhibited androgen-responsive LNCaP cell growth through downregulation of AR expression [197], whereas ER $\beta$ mediated the inhibition in androgen-irresponsive and AR non-expressing DU145 cells through modulations of NF- $\mathrm{KB}$ signaling [170] and upregulation of hsa-miR-765 expression to suppress oncogenic HMGA1 protein expression [198] (Figure 2). Regarding the clinical relevance, the ER $\beta$-hsa-miR-765-HMGA1 signaling axis was also observed in the patients treated with fulvestrant [198]. Furthermore, the drug impaired cell migration and invasion of PCa cells possibly via reduction of filopodia/stress fibers formations, providing the mechanistic insights of how fulvestrant inhibited PCa cell growth and its metastatic behaviors [198] (Figure 2).

In the early clinical trial of fulvestrant in castration-resistant PCa (CRPC) with a single dose of $500 \mathrm{mg}$ on day 0 and then $250 \mathrm{mg}$ on day 14 , day 28 , and monthly thereafter for six months in 
20 patients, the treatment was well-tolerated but no clinical or PSA response was obtained [199]. However, the subsequent trial with $500 \mathrm{mg}$ fulvestrant every 14 days for the first month and $250 \mathrm{mg}$ monthly thereafter in seven highly pretreated CRPC patients demonstrated initial reduction of PSA levels in six of these patients even though the levels increased after the dose was reduced to $250 \mathrm{mg}$ [200]. This observation clearly implied dose-dependent responses of fulvestrant in PCa [200] and thus warranted further studies of dose optimization for fulvestrant therapy in PCa patients. Importantly, comparing with chemotherapy that is not always the option for elderly and fragile patients with co-morbidities, fulvestrant treatment with low toxicity profiles could be specifically beneficial to these patients. For high-dose treatment, the possible increased toxicity may hamper the continuation of the treatment in the patients. However, the improved therapeutic efficacy and no new safety concerns identified for high-dose $(500 \mathrm{mg})$ fulvestrant treatment in recurrent and metastatic breast cancer patients compared with the low-dose $(250 \mathrm{mg})$ treatment were reported [201]. These promising results should lead toward future trials on high-dose fulvestrant in PCa patients.

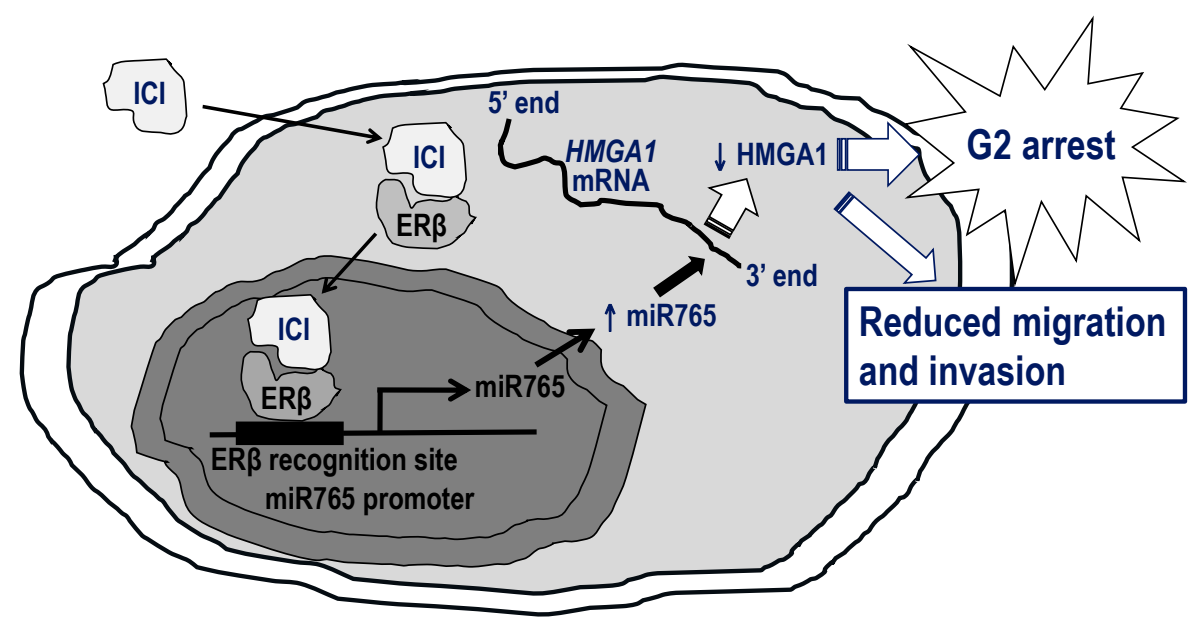

Figure 2. The proposed mechanism underlying the inhibitory effects of fulvestrant (ICI) on prostate cancer cells. Fulvestrant (ICI) interacts with ER $\beta$ and the complexes translocate into the nucleus to transactivate the promoter of hsa-miR765 at the ER $\beta$ recognition site. Upon stimulation, the level of hsa-miR765 increases and the miRNAs recognize the 3'-UTR of its target HMGA1 transcripts to predominantly suppress the translation and, at least in part, reduce the transcript stability, resulting in reduction of HMGA1 protein expression in the cells. Eventually, the reduction induces G2 cell cycle arrest and interferes with the metastatic potential of the cells.

\section{Significance of a G-Protein-Coupled Receptor GPR30 and Its Therapeutic Potential in PCa}

In addition to receptor-mediated transcriptional regulations of target genes in estrogenic actions, estrogens are able to trigger rapid signaling cascades initiated at the plasma membrane [202,203]. They mediated through activations of MAP kinases, PI3K kinase, protein kinase $C$ and protein phosphatases and/or through releases of intracellular cAMP, cGMP and calcium [202,203]. By ligand-binding studies using radioactive labeled estrogens or membrane-impermeable fluorescent dye-labeled estrogen conjugated with bovine serum albumin ( $E_{2}-B S A$ conjugates), estrogen-binding sites were demonstrated to be at the plasma membrane [204]. In addition, these rapid estrogenic signaling responses were stimulated by membrane-impermeable $\mathrm{E}_{2}$-BSA conjugates, independent of cytosolic ERs [205-208]. Previous studies also suggested that there were approximately $5 \%-10 \%$ of cellular ER $\alpha$ and/or ER $\beta$ and their splice variants at the plasma membrane, instead of in cytoplasm, responsible for these non-genomic estrogenic responses [209-213].

Besides ER $\alpha$ and ER $\beta$, an orphan G-protein-coupled receptor (GPR30) showed high affinity but low-capacity binding to estrogens/phytoestrogens/antiestrogens/selective estrogen receptor modulators. It was detected at the plasma membrane and endoplasmic reticulum, also referred to as 
the G-protein-coupled estrogen receptor (GPER) [214-217]. It belongs to the family of 7-transmembrane G-protein-coupled receptors [218]. It was speculated that GPR30 together with ER $\alpha$ and/or ER $\beta$ elicited non-genomic estrogenic responses initiated at the plasma membrane in the estrogen-targeted cells [219]. By estrogenic stimulation, the receptor induces rapid but transient Erk1/2 activation to promote cell proliferation in ER $\alpha / E R \beta$-negative breast cancer cells as well as in endometrial, ovarian, and thyroid cancer cells [220-222]. On the contrary, GPR30 activation suppressed in vitro growth of normal and malignant bladder urothelial cells [223]. We also demonstrated the inhibitory functions of this receptor upon activation in PCa in both in vitro and in vivo models [224]. These implied the dual roles of GPR30 in controlling cell growth in a cell type-specific manner.

A number of estrogenic responses that are mediated through ER $\alpha$ and ER $\beta$ had been reflected by the phenotypes of the single and double knockout mice of these two receptors (ER $\alpha K O, E R \beta K O$ and $E R \alpha \beta K O)$ [171-175]. However, some estrogen-dependent phenotypes, independent of ER $\alpha$ and $E R \beta$, were observed in ER $\alpha \beta K O$ mice, highlighting the presence of additional receptor-like GPR30 for estrogen-dependent physiology $[225,226]$. In ER $\alpha \beta K O$ mice with no ERs, pancreatic $\beta$-cells retained estrogenic protection from apoptosis [225]. Knocking out of GPR30 in these mice impaired the protective effects and they were susceptible to apoptotic stress in pancreatic islet, implicating the significance of GPR30 in this estrogenic protection [225].

Regarding GPR30-mediated signaling, its involvements mainly in cell-growth stimulation had been studied in various estrogen-related cancers since Filardo et al. [214] first described the estrogen-mediated and GPR30-dependent activation of MAP kinase Erk1/2 via transactivation of epidermal growth factor receptor in breast cancer cells. Estrogen $17 \beta$-estradiol and antiestrogen fulvestrant (ICI-182,780) induced a rapid but transient activation of Erk1/2 in ER $\alpha / E R \beta$-negative breast cancer cells SKBR3 that express GPR30 but not in GPR30 non-expressing MB-MDA231 cells [214]. It is mediated through $G \beta \gamma$-mediated signaling as $G \beta \gamma$ sequestrant peptide inhibited the activation [214]. For mechanisms underlying the rapid restoration of Erk1/2 activity to the baseline level, Filardo et al. [227] demonstrated that estrogen via GPR30 simultaneously activated adenylyl cyclase (AC) to increase intracellular cAMP that eventually attenuates Erk1/2 activity, then resulting in cell-growth stimulation in the cells.

To adequately delineate the GPR30-mediated signaling, identification of G-1 (1-[4-(6-romobenzo [1,3]dioxol-5yl)-3a,4,5,9b-tetrahydro-3H-cyclopenta[c]quinolin-8-yl]-ethanone) by virtual and biomolecular screening approaches as a GPR30-selective agonist [228] is critical, especially for studying the functional roles of GPR30 in the cells that co-expressed ER $\alpha$ and/or ER $\beta$. Importantly, G-1 displayed no significant binding to either ER $\alpha$ or ER $\beta$ [228]. Thus, G-1 specifically activates the GPR30-mediated signaling without interferences of ER $\alpha$ - and/or ER $\beta$-associated complications. In BG-1 ovarian cancer cells and SKBR3 breast cancer cells, G-1 stimulated cell proliferation through transient activation of Erk1/2 and induction of c-fos and cyclin D1 expression [222].

GPR30-mediated signaling for cell-growth inhibition is relatively less understood. In human bladder urothelial cells, G-1 inhibited cell growth but failed to induce c-fos and cyclin D1 expression [223]. However, estrogen stimulated urothelial cell growth with induction of these genes expression [223]. Overexpression of GPR30 abolished the estrogen-induced c-fos and cyclin D1 expression, whereas siRNA knockdown of this receptor increased gene expression, suggesting that GPR30 reduced proliferative effects of estrogens on urothelial cells by hampering the estrogen-induced genes expression [223].

For PCa, we reported dose-dependent cell-growth inhibition by G-1 through GPR30-dependent G2 cell cycle arrest [224]. The sensitivity to G-1 depends on the level of GPR30 in PCa cells as the IC50 for high GPR30-expressing PC-3 cells is lower than that for low GPR30-expressing DU145 cells [224]. Expression of GPR30 obtained from gene expression microarray databases of Vanaja et al.'s [229] and Varambally et al.'s [230] studies and also our cohort of samples [224] showed variations in the expression among clinical samples with slight reduction in PCa as compared to normal tissues, suggesting that the sensitivity to G-1 among patients may be different and expression status of GPR30 
could be used as a biomarker for prediction of a patient's outcomes for GPR30-targeted therapy in future clinical trials.

Mechanistically, activation of GPR30 by G-1 inhibited PCa cell growth through sustained activation of Erk1/2, c-jun/c-fos-dependent upregulation of p21 expression, and downregulation of G2-checkpoint regulators (cyclin A2, cyclin B1, cdc25c, and cdc2) expression by reduced phosphorylation of their common transcriptional factor NF-YA, resulting in arrest of PCa cell growth at G2 phase [224] (Figure 3). In addition, G-1 inhibited growths of both androgen-dependent and androgen-independent PCa cells in vitro and PC-3 xenografts in vivo [224]. Importantly, G-1 elicited no growth or any histological change in the prostate of intact mice and did not affect cell growth of quiescent BPH-1, an immortalized benign prostatic epithelial cell line, indicating the safety of this therapy [224]. The therapeutic actions of G-1 and their relationships with androgen in vivo was investigated using the $\mathrm{LNCaP}$ xenograft to model PCa growth during the androgen-sensitive (AS) versus the castration-resistant (CR) phase recapitulated the natural history of PCa progression 231]. GPR30 expression was reduced by androgen via AR and castration upregulated the expression [231]. In human specimens, metastatic CRPC expressed a high level of GPR30 [231]. Regarding the therapeutic actions of G-1, this GPR30 agonist specifically inhibited CR but not AS tumors with marked neutrophil infiltration in the affected tumors and low risk of toxicity [231]. These preclinical data lay a crucial foundation for further development of GPR30-targeted therapy for the patients.

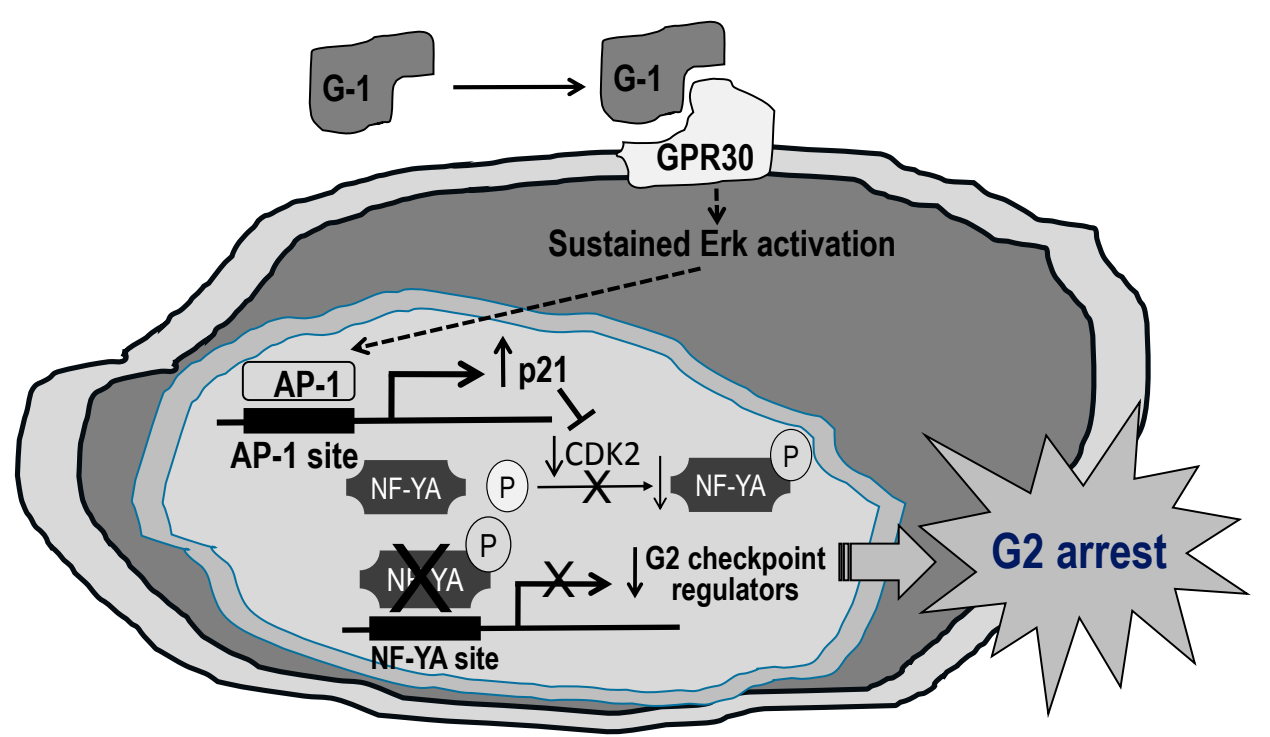

Figure 3. The proposed mechanism underlying the inhibitory effects of GPR30 activation by G-1 on prostate cancer cell growth. Upon GPR30 activation by G-1, Erk1/2 are activated with nuclear translocation of phosphorylated Erk1/2. The activation is sustained for up to four days. The sustained Erk1/2 activation stimulates AP-1 proteins (i.e., increased levels of phosphorylated c-fox and c-jun) to induce p21 expression. As p21 is a negative regulator of CDK1 which activates NF-YA, the increased p21 reduces the levels of CDK1 and active NF-YA, resulting in downregulation of G2 checkpoint regulators expression including CCNA, CCNB, cdc2 and cdc25C to induce G2 cell cycle arrest and eventually inhibit the cell growth.

It was well-established that duration of Erk1/2 activation dictates the cell fate with transient Erk1/2 activation leading to cell survival and proliferation whereas sustained activation transmitting antiproliferative signals [232,233]. In concordance, we reported that G-1 induced sustained nuclear accumulation of phosphorylated Erk1/2 in PC-3 cells but not in MCF-7 breast cancer cells that only showed transient accumulation [224]. Transient activation in breast cancer cells is attributed to the negative feedback via $\mathrm{G} \alpha$-protein-mediated activation of AC [227]. However, the underlying 
mechanism about how to sustain Erk1/2 activation eventually to inhibit the growth of PCa cells remains unclear.

In addition to controlling cancer cell growth, GPR30 activation by antiestrogen tamoxifen upregulated expression of Connective Tissue Growth Factor (CTGF) via transactivation of its promoter by AP-1 to promote cell migration in SKBR3 breast cancer cells [234], shedding light onto the GPR30-mediated stimulatory effects on breast cancer cell metastatic potentials. In line with this observation, high expression of GPR30 correlates with clinicopathological biomarkers for poor outcomes and also with increased tumor size and metastasis in clinical breast cancers [235]. However, activation of GPR30 by its agonists including G-1, estrogen, fulvestrant and tamoxifen attenuates EGF-induced rapid mobilization of urokinase plasminogen activator receptor to inhibit migration of ovarian cancer cells [236]. Similar to cell-growth regulations, these opposite data also suggest the dual roles of GPR30 in controlling cell migration, depending on cell types and being mediated via different mechanisms. Whether and how GPR30 is involved in PCa cell migration and even invasion are yet to be determined. Future studies delineating the functional significance of GPR30 and its underlying mechanisms in governing these metastatic behaviors of PCa are warranted.

Recently, doubts about the specificity of G-1 have emerged. Instead of binding to GPR30, G-1 was demonstrated to directly interact with ER $\alpha 36$, a $36 \mathrm{kDa}$ membrane-localized splice variant of $\mathrm{ER} \alpha$, to activate Erk1/2 signaling in SKBR3 cells [237]. In this activation, GPR30 is involved in controlling ER $\alpha 36$ expression [237]. It prompts a concern about the exact molecular target of G-1 in cell signaling. Future pharmacological developments of more specific GPR30 agonists and antagonists are needed to reveal the exact functional and mechanistic roles of this receptor in PCa and also other estrogen-related cancers.

\section{Conclusions}

Nearly three-quarters of a century has passed since the first demonstration of androgen dependence of PCa by Huggins and Hodges, leading to the eventual establishment of androgen ablation therapy for patients. This therapeutic approach remained as the mainstay PCa treatment for several decades. Throughout these years, a tremendous amount of research efforts disclosed the importance of estrogenic and antiestrogenic signaling via their receptors like ER $\alpha, E R \beta$ and GPR30 in controlling PCa growth and its metastatic phenotypes. Mechanistically, the molecular and functional consequences of these signals in PCa have been investigated and gradually revealed. Yet, the exact molecular networks of these estrogenic and antiestrogenic signaling in PCa have not been fully deciphered. The roles of ER $\beta$ in preventing EMT in PCa due to downregulation of this receptor expression frequently found in high-grade cancers highlighted the importance of this receptor in controlling PCa aggressiveness. Thus, the mechanism underlying this downregulation and approaches for hindering the alteration could be the direction for future study. Regarding GPR30, the current preclinical data demonstrated the therapeutic potential of the G-1-induced GPR30 activation for PCa. The therapy efficacy and toxicity should be further evaluated in clinical trials for metastatic CRPC patients. Furthermore, there are emerging concerns about the specificity of G-1, the identification of more specific derivatives could therefore be beneficial for developments of this GPR30-targeted therapy.

Acknowledgments: This work was financially supported by Hong Kong Research Grant Council—General Research Fund (Project 467612) and the fund also covers the costs to publish in open access.

Author Contributions: Kin-Mang Lau and Ka-Fai To conceived the outlines of the review and wrote the paper.

Conflicts of Interest: The authors declare no conflict of interest. The funding sponsors had no role in the writing of the manuscript and in the decision to publish the paper.

\section{References}

1. American Cancer Society-Cancer Statistics Center. Prostate. Available online: https://cancerstatisticscenter. cancer.org/\#/cancer-site/Prostate (assessed on 18 February 2016). 
2. Cook, P.J.; Doll, R.; Fellingham, S.A. A mathematical model for the age distribution of cancer in man. Int. J. Cancer 1969, 4, 93-112. [CrossRef] [PubMed]

3. Ross, R.K. Epidemiology of prostate cancer and bladder cancer: An overview. Cancer Treat Res. 1996, 88, 1-11. [PubMed]

4. Platz, E.A.; Rimm, E.B.; Willett, W.C.; Kantoff, P.W.; Giovannucci, E. Racial variation in prostate cancer incidence and in hormonal system markers among male health professionals. J. Natl. Cancer Inst. 2000, 92, 2009-2017. [CrossRef] [PubMed]

5. Farkas, A.; Marcella, S.; Rhoads, G.G. Ethnic and racial differences in prostate cancer incidence and mortality. Ethn. Dis. 2000, 10, 69-75. [PubMed]

6. Hoffman, R.M.; Gilliland, F.D.; Eley, J.W.; Harlan, L.C.; Stephenson, R.A.; Stanford, J.L.; Albertson, P.C.; Hamilton, A.S.; Hunt, W.C.; Potosky, A.L. Racial and ethnic differences in advanced-stage prostate cancer: The prostate cancer outcomes study. J. Natl. Cancer Inst. 2001, 93, 388-395. [CrossRef] [PubMed]

7. Fowler, J.E., Jr.; Bigler, S.A.; Lynch, C.; Wilson, S.S.; Farabaugh, P.B. Prospective study of correlations between biopsy-detected high grade prostatic intraepithelial neoplasia, serum prostate specific antigen concentration, and race. Cancer 2001, 91, 1291-1296. [CrossRef]

8. Powell, I.J.; Meyskens, F.L., Jr. African American men and hereditary/familial prostate cancer: Intermediate-risk populations for chemoprevention trials. Urology 2001, 57, 178-181. [CrossRef]

9. Du, X.L.; Fang, S.; Coker, A.L.; Sanderson, M.; Aragaki, C.; Cormier, J.N.; Xing, Y.; Gor, B.J.; Chan, W. Racial disparity and socioeconomic status in association with survival in older men with local/regional stage prostate carcinoma: Findings from a large community-based cohort. Cancer 2006, 106, 1276-1285. [CrossRef] [PubMed]

10. Virnig, B.A.; Baxter, N.N.; Habermann, E.B.; Feldman, R.D.; Bradley, C.J. A matter of race: Early-versus late-stage cancer diagnosis. Health Aff. 2009, 28, 160-168. [CrossRef] [PubMed]

11. Rebbeck, T.R.; Devesa, S.S.; Chang, B.L.; Bunker, C.H.; Cheng, I.; Cooney, K.; Eeles, R.; Fernandez, P.; Giri, V.N.; Gueye, S.M.; et al. Global patterns of prostate cancer incidence, aggressiveness, and mortality in men of African descent. Prostate Cancer 2013, 2013, 560857. [CrossRef] [PubMed]

12. Watanabe, M.; Nakayama, T.; Shiraishi, T.; Stemmermann, G.N.; Yatani, R. Comparative studies of prostate cancer in japan versus the United States. A review. Urol. Oncol. 2000, 5, 274-283. [CrossRef]

13. Ellem, S.J.; Risbridger, G.P. Treating prostate cancer: A rationale for targeting local oestrogens. Nat. Rev. Cancer 2007, 7, 621-627. [CrossRef] [PubMed]

14. Shimizu, H.; Ross, R.K.; Bernstein, L.; Yatani, R.; Henderson, B.E.; Mack, T.M. Cancers of the prostate and breast among Japanese and white immigrants in Los Angeles county. Br. J. Cancer 1991, 63, 963-966. [CrossRef] [PubMed]

15. McCredie, M.; Coates, M.; Grulich, A. Cancer incidence in migrants to New South Wales (Australia) from the Middle East, 1972-1991. Cancer Causes Control 1994, 5, 414-421. [CrossRef] [PubMed]

16. Whittemore, A.S.; Kolonel, L.N.; Wu, A.H.; John, E.M.; Gallagher, R.P.; Howe, G.R.; Burch, J.D.; Hankin, J.; Dreon, D.M.; West, D.W.; et al. Prostate cancer in relation to diet, physical activity, and body size in blacks, whites, and Asians in the United States and Canada. J. Natl. Cancer Inst. 1995, 87, 652-661. [CrossRef] [PubMed]

17. Angwafo, F.F. Migration and prostate cancer: An international perspective. J. Natl. Med. Assoc. 1998, 90, S720-S723. [PubMed]

18. Guileyardo, J.M.; Johnson, W.D.; Welsh, R.A.; Akazaki, K.; Correa, P. Prevalence of latent prostate carcinoma in two U.S. Populations. J. Natl. Cancer Inst. 1980, 65, 311-316. [PubMed]

19. Sakr, W.A.; Grignon, D.J.; Haas, G.P.; Schomer, K.L.; Heilbrun, L.K.; Cassin, B.J.; Powell, J.; Montie, J.A.; Pontes, J.E.; Crissman, J.D. Epidemiology of high grade prostatic intraepithelial Neoplasia. Pathol. Res. Pract. 1995, 191, 838-841. [CrossRef]

20. Sakr, W.A.; Ward, C.; Grignon, D.J.; Haas, G.P. Epidemiology and molecular biology of early prostatic neoplasia. Mol. Urol. 2000, 4, 109-113. [PubMed]

21. Selman, S.H. "Latent" carcinoma of the prostate: A medical misnomer? Urology 2000, 56, 708-711. [CrossRef]

22. Rich, A.R. On the frequency of occurrence of occult carcinoma of the prostrate. 1934. Int. J. Epidemiol. 2007, 36, 274-277. [CrossRef] [PubMed]

23. Andrews, G.S. Latent carcinoma of the prostate. J. Clin. Pathol. 1949, 2, 197-208. [CrossRef] [PubMed]

24. Franks, L.M. Latent carcinoma of the prostate. J. Pathol. Bacteriol. 1954, 68, 603-616. [CrossRef] [PubMed] 
25. Griffiths, K. Estrogens and prostatic disease. International prostate health council study group. Prostate 2000, 45, 87-100. [CrossRef]

26. Hill, P.; Garbaczewski, L.; Walker, A.R. Age, environmental factors and prostatic cancer. Med. Hypotheses 1984, 14, 29-39. [CrossRef]

27. Henderson, B.E.; Bernstein, L.; Ross, R.K.; Depue, R.H.; Judd, H.L. The early in utero oestrogen and testosterone environment of blacks and whites: Potential effects on male offspring. Br. J. Cancer 1988, 57, 216-218. [CrossRef] [PubMed]

28. De Jong, F.H.; Oishi, K.; Hayes, R.B.; Bogdanowicz, J.F.; Raatgever, J.W.; van der Maas, P.J.; Yoshida, O.; Schroeder, F.H. Peripheral hormone levels in controls and patients with prostatic cancer or benign prostatic hyperplasia: Results from the Dutch-Japanese case-control study. Cancer Res. 1991, 51, 3445-3450. [PubMed]

29. Bosland, M.C. The role of steroid hormones in prostate carcinogenesis. J. Natl. Cancer Inst. Monogr. 2000, 27, 39-66. [CrossRef] [PubMed]

30. Ross, R.; Bernstein, L.; Judd, H.; Hanisch, R.; Pike, M.; Henderson, B. Serum testosterone levels in healthy young black and white men. J. Natl. Cancer Inst. 1986, 76, 45-48. [PubMed]

31. Rohrmann, S.; Nelson, W.G.; Rifai, N.; Brown, T.R.; Dobs, A.; Kanarek, N.; Yager, J.D.; Platz, E.A. Serum estrogen, but not testosterone, levels differ between black and white men in a nationally representative sample of Americans. J. Clin. Endocrinol. Metab. 2007, 92, 2519-2525. [CrossRef] [PubMed]

32. Abd Elmageed, Z.Y.; Moroz, K.; Srivastav, S.K.; Fang, Z.; Crawford, B.E.; Moparty, K.; Thomas, R.; Abdel-Mageed, A.B. High circulating estrogens and selective expression of $\operatorname{Er} \beta$ in prostate tumors of Americans: Implications for racial disparity of prostate cancer. Carcinogenesis 2013, 34, 2017-2023. [CrossRef] [PubMed]

33. Nomura, A.; Heilbrun, L.K.; Stemmermann, G.N.; Judd, H.L. Prediagnostic serum hormones and the risk of prostate cancer. Cancer Res. 1988, 48, 3515-3517. [PubMed]

34. Hsing, A.W.; Comstock, G.W. Serological precursors of cancer: Serum hormones and risk of subsequent prostate cancer. Cancer Epidemiol. Biomark. Prev. 1993, 2, 27-32.

35. Comstock, G.W.; Gordon, G.B.; Hsing, A.W. The relationship of serum dehydroepiandrosterone and its sulfate to subsequent cancer of the prostate. Cancer Epidemiol. Biomark. Prev. 1993, 2, 219-221.

36. Gann, P.H.; Hennekens, C.H.; Ma, J.; Longcope, C.; Stampfer, M.J. Prospective study of sex hormone levels and risk of prostate cancer. J. Natl. Cancer Inst. 1996, 88, 1118-1126. [CrossRef] [PubMed]

37. Dorgan, J.F.; Albanes, D.; Virtamo, J.; Heinonen, O.P.; Chandler, D.W.; Galmarini, M.; McShane, L.M.; Barrett, M.J.; Tangrea, J.; Taylor, P.R. Relationships of serum androgens and estrogens to prostate cancer risk: Results from a prospective study in Finland. Cancer Epidemiol. Biomark. Prev. 1998, 7, 1069-1074.

38. Barrett-Connor, E.; Garland, C.; McPhillips, J.B.; Khaw, K.T.; Wingard, D.L. A prospective, population-based study of androstenedione, estrogens, and prostatic cancer. Cancer Res. 1990, 50, 169-173. [PubMed]

39. Vermeulen, A.; Rubens, R.; Verdonck, L. Testosterone secretion and metabolism in male senescence. J. Clin. Endocrinol. Metab. 1972, 34, 730-735. [CrossRef] [PubMed]

40. Gray, A.; Feldman, H.A.; McKinlay, J.B.; Longcope, C. Age, disease, and changing sex hormone levels in middle-aged men: Results of the Massachusetts male aging study. J. Clin. Endocrinol. Metab. 1991, 73, 1016-1025. [CrossRef] [PubMed]

41. Gray, A.; Berlin, J.A.; McKinlay, J.B.; Longcope, C. An examination of research design effects on the association of testosterone and male aging: Results of a meta-analysis. J. Clin. Epidemiol. 1991, 44, 671-684. [CrossRef]

42. Kaufman, J.M.; Kaufman, J.L.; Borges, F.D. Immediate salvage procedure for infected penile prosthesis. J. Urol. 1998, 159, 816-818. [CrossRef]

43. Vermeulen, A.; Kaufman, J.M.; Goemaere, S.; van Pottelberg, I. Estradiol in elderly men. Aging Male 2002, 5, 98-102. [CrossRef] [PubMed]

44. Krieg, M.; Nass, R.; Tunn, S. Effect of aging on endogenous level of $5 \alpha$-dihydrotestosterone, testosterone, estradiol, and estrone in epithelium and stroma of normal and hyperplastic human prostate. J. Clin. Endocrinol. Metab. 1993, 77, 375-381. [PubMed]

45. Bartsch, G.; Rittmaster, R.S.; Klocker, H. Dihydrotestosterone and the concept of $5 \alpha$-reductase inhibition in human benign prostatic hyperplasia. Eur. Urol. 2000, 37, 367-380. [CrossRef] [PubMed]

46. Tunn, S.; Hochstrate, H.; Grunwald, I.; Fluchter, S.H.; Krieg, M. Effect of aging on kinetic parameters of 5 $\alpha$-reductase in epithelium and stroma of normal and hyperplastic human prostate. J. Clin. Endocrinol. Metab. 1988, 67, 979-985. [CrossRef] [PubMed] 
47. Zumoff, B.; Strain, G.W.; Kream, J.; O'Connor, J.; Rosenfeld, R.S.; Levin, J.; Fukushima, D.K. Age variation of the 24-hour mean plasma concentrations of androgens, estrogens, and gonadotropins in normal adult men. J. Clin. Endocrinol. Metab. 1982, 54, 534-538. [CrossRef] [PubMed]

48. Leav, I.; Merk, F.B.; Ofner, P.; Goodrich, G.; Kwan, P.W.; Stein, B.M.; Sar, M.; Stumpf, W.E. Bipotentiality of response to sex hormones by the prostate of castrated or hypophysectomized dogs. Direct effects of estrogen. Am. J. Pathol. 1978, 93, 69-92. [PubMed]

49. Merk, F.B.; Warhol, M.J.; Kwan, P.W.; Leav, I.; Alroy, J.; Ofner, P.; Pinkus, G.S. Multiple phenotypes of prostatic glandular cells in castrated dogs after individual or combined treatment with androgen and estrogen. Morphometric, ultrastructural, and cytochemical distinctions. Lab. Investig. 1986, 54, 442-456. [PubMed]

50. Levine, A.C.; Ren, M.; Huber, G.K.; Kirschenbaum, A. The effect of androgen, estrogen, and growth factors on the proliferation of cultured fibroblasts derived from human fetal and adult prostates. Endocrinology 1992, 130, 2413-2419. [PubMed]

51. Bruengger, A.; Mariotti, A.; Rohr, H.P.; Bartsch, G.; Stahel, W.; Wiederkehr, P.; Carmichael, S.W.; Mawhinney, M.G. Androgen and estrogen effect on guinea pig seminal vesicle muscle: A combined stereological and biochemical study. Prostate 1986, 9, 303-310. [CrossRef] [PubMed]

52. Tam, C.C.; Wong, Y.C.; White, F.H.; Fowler, J.P. Morphometric and stereological study of the glandular epithelium of the lateral prostate of the intact and castrated guinea pig. Prostate 1991, 19, 1-22. [CrossRef] [PubMed]

53. Tam, C.C.; Wong, Y.C. Ultrastructural study of the effects of $17 \beta$-oestradiol on the lateral prostate and seminal vesicle of the castrated guinea pig. Acta Anat. 1991, 141, 51-62. [PubMed]

54. Ricciardelli, C.; Horsfall, D.J.; Sykes, P.J.; Marshall, V.R.; Tilley, W.D. Effects of oestradiol-17 $\beta$ and $5 \alpha$-dihydrotestosterone on guinea-pig prostate smooth muscle cell proliferation and steroid receptor expression in vitro. J. Endocrinol. 1994, 140, 373-383. [CrossRef] [PubMed]

55. Risbridger, G.P.; Wang, H.; Frydenberg, M.; Cunha, G. The metaplastic effects of estrogen on mouse prostate epithelium: Proliferation of cells with basal cell phenotype. Endocrinology 2001, 142, 2443-2450. [CrossRef] [PubMed]

56. Arai, Y.; Mori, T.; Suzuki, Y.; Bern, H.A. Long-term effects of perinatal exposure to sex steroids and diethylstilbestrol on the reproductive system of male mammals. Int. Rev. Cytol. 1983, 84, 235-268. [PubMed]

57. Vorherr, H.; Messer, R.H.; Vorherr, U.F.; Jordan, S.W.; Kornfeld, M. Teratogenesis and carcinogenesis in rat offspring after transplacental and transmammary exposure to diethylstilbestrol. Biochem. Pharmacol. 1979, 28, 1865-1877. [CrossRef]

58. Arai, Y.; Suzuki, Y.; Nishizuka, Y. Hyperplastic and metaplastic lesions in the reproductive tract of male rats induced by neonatal treatment with diethylstilbestrol. Virchows Arch. A Pathol. Anat. Histol. 1977, 376, 21-28. [CrossRef] [PubMed]

59. McLachlan, J.A.; Newbold, R.R.; Bullock, B. Reproductive tract lesions in male mice exposed prenatally to diethylstilbestrol. Science 1975, 190, 991-992. [CrossRef] [PubMed]

60. Pylkkanen, L.; Santti, R.; Newbold, R.; McLachlan, J.A. Regional differences in the prostate of the neonatally estrogenized mouse. Prostate 1991, 18, 117-129. [CrossRef] [PubMed]

61. vom Saal, F.S.; Timms, B.G.; Montano, M.M.; Palanza, P.; Thayer, K.A.; Nagel, S.C.; Dhar, M.D.; Ganjam, V.K.; Parmigiani, S.; Welshons, W.V. Prostate enlargement in mice due to fetal exposure to low doses of estradiol or diethylstilbestrol and opposite effects at high doses. Proc. Natl. Acad. Sci. USA 1997, 94, 2056-2061. [CrossRef] [PubMed]

62. Rajfer, J.; Coffey, D.S. Sex steroid imprinting of the immature prostate. Long-term effects. Investig. Urol. 1978, 16, 186-190.

63. Prins, G.S. Neonatal estrogen exposure induces lobe-specific alterations in adult rat prostate androgen receptor expression. Endocrinology 1992, 130, 3703-3714. [CrossRef] [PubMed]

64. Prins, G.S.; Ho, S.M. Early-life estrogens and prostate cancer in an animal model. J. Dev. Orig. Health Dis. 2010, 1, 365-370. [CrossRef] [PubMed]

65. Prins, G.S.; Marmer, M.; Woodham, C.; Chang, W.; Kuiper, G.; Gustafsson, J.A.; Birch, L. Estrogen receptor- $\beta$ messenger ribonucleic acid ontogeny in the prostate of normal and neonatally estrogenized rats. Endocrinology 1998, 139, 874-883. [CrossRef] [PubMed] 
66. Leav, I.; Merk, F.B.; Kwan, P.W.; Ho, S.M. Androgen-supported estrogen-enhanced epithelial proliferation in the prostates of intact noble rats. Prostate 1989, 15, 23-40. [CrossRef] [PubMed]

67. Ho, S.M.; Yu, M. Hormonal regulation of nuclear type II estrogen binding sites in the dorsolateral prostate of noble rats. J. Steroid Biochem. Mol. Biol. 1995, 52, 233-238. [CrossRef]

68. Noble, R.L. Sex steroids as a cause of adenocarcinoma of the dorsal prostate in NB rats, and their influence on the growth of transplants. Oncology 1977, 34, 138-141. [CrossRef] [PubMed]

69. Noble, R.L. The development of prostatic adenocarcinoma in NB rats following prolonged sex hormone administration. Cancer Res. 1977, 37, 1929-1933. [PubMed]

70. Drago, J.R. The induction of NB rat prostatic carcinomas. Anticancer Res. 1984, 4, 255-256. [PubMed]

71. Ho, S.M.; Leav, I.; Merk, F.B.; Yu, M.; Kwan, P.W.; Ziar, J. Induction of atypical hyperplasia, apoptosis, and type II estrogen-binding sites in the ventral prostates of noble rats treated with testosterone and pharmacologic doses of estradiol-17 $\beta$. Lab. Investig. 1995, 73, 356-365. [PubMed]

72. Bosland, M.C.; Ford, H.; Horton, L. Induction at high incidence of ductal prostate adenocarcinomas in NBL/CR and sprague-dawley HSD:SD rats treated with a combination of testosterone and estradiol-17 $\beta$ or diethylstilbestrol. Carcinogenesis 1995, 16, 1311-1317. [CrossRef] [PubMed]

73. Wong, Y.C.; Wang, Y.Z.; Tam, N.N. The prostate gland and prostate carcinogenesis. Ital. J. Anat. Embryol. 1998, 103, 237-252. [PubMed]

74. Bosland, M.C. Animal models for the study of prostate carcinogenesis. J. Cell. Biochem. Suppl. 1992, 16H, 89-98. [CrossRef] [PubMed]

75. Bostwick, D.G.; Montironi, R. Prostatic intraepithelial neoplasia and the origins of prostatic carcinoma. Pathol. Res. Pract. 1995, 191, 828-832. [CrossRef]

76. Shin, H.J.; Ro, J.Y. Prostatic intraepithelial neoplasia: A potential precursor lesion of prostatic adenocarcinoma. Yonsei Med. J. 1995, 36, 215-231. [CrossRef] [PubMed]

77. Haggman, M.J.; Macoska, J.A.; Wojno, K.J.; Oesterling, J.E. The relationship between prostatic intraepithelial neoplasia and prostate cancer: Critical issues. J. Urol. 1997, 158, 12-22. [CrossRef] [PubMed]

78. Zlotta, A.R.; Schulman, C.C. Clinical evolution of prostatic intraepithelial neoplasia. Eur. Urol. 1999, 35, 498-503. [CrossRef] [PubMed]

79. Alcaraz, A.; Barranco, M.A.; Corral, J.M.; Ribal, M.J.; Carrio, A.; Mallofre, C.; Llopis, J.; Cetina, A.; Alvarez-Vijande, R. High-grade prostate intraepithelial neoplasia shares cytogenetic alterations with invasive prostate cancer. Prostate 2001, 47, 29-35. [CrossRef] [PubMed]

80. Nelson, W.G.; De Marzo, A.M.; Isaacs, W.B. Prostate cancer. N. Engl. J. Med. 2003, 349, 366-381. [CrossRef] [PubMed]

81. Merrimen, J.L.; Jones, G.; Walker, D.; Leung, C.S.; Kapusta, L.R.; Srigley, J.R. Multifocal high grade prostatic intraepithelial neoplasia is a significant risk factor for prostatic adenocarcinoma. J. Urol. 2009, 182, 485-490. [CrossRef] [PubMed]

82. Wang, Y.; Hayward, S.W.; Donjacour, A.A.; Young, P.; Jacks, T.; Sage, J.; Dahiya, R.; Cardiff, R.D.; Day, M.L.; Cunha, G.R. Sex hormone-induced carcinogenesis in RB-deficient prostate tissue. Cancer Res. 2000, 60, 6008-6017. [PubMed]

83. Nicholson, T.M.; Ricke, E.A.; Marker, P.C.; Miano, J.M.; Mayer, R.D.; Timms, B.G.; vom Saal, F.S.; Wood, R.W.; Ricke, W.A. Testosterone and $17 \beta$-estradiol induce glandular prostatic growth, bladder outlet obstruction, and voiding dysfunction in male mice. Endocrinology 2012, 153, 5556-5565. [CrossRef] [PubMed]

84. Ricke, W.A.; McPherson, S.J.; Bianco, J.J.; Cunha, G.R.; Wang, Y.; Risbridger, G.P. Prostatic hormonal carcinogenesis is mediated by in situ estrogen production and estrogen receptor alpha signaling. FASEB J. 2008, 22, 1512-1520. [CrossRef] [PubMed]

85. Ellem, S.J.; Schmitt, J.F.; Pedersen, J.S.; Frydenberg, M.; Risbridger, G.P. Local aromatase expression in human prostate is altered in malignancy. J. Clin. Endocrinol. Metab. 2004, 89, 2434-2441. [CrossRef] [PubMed]

86. Celhay, O.; Yacoub, M.; Irani, J.; Dore, B.; Cussenot, O.; Fromont, G. Expression of estrogen related proteins in hormone refractory prostate cancer: Association with tumor progression. J. Urol. 2010, 184, 2172-2178. [CrossRef] [PubMed]

87. Roberts, M.; Wallace, J.; Jeltsch, J.M.; Berry, M. The 5' flanking region of the human PS2 gene mediates its transcriptional activation by estrogen in mcf-7 cells. Biochem. Biophys. Res. Commun. 1988, 151, 306-313. [CrossRef] 
88. Clarke, C.L. Cell-specific regulation of progesterone receptor in the female reproductive system. Mol. Cell. Endocrinol. 1990, 70, 29-33. [CrossRef]

89. Webb, P.; Lopez, G.N.; Uht, R.M.; Kushner, P.J. Tamoxifen activation of the estrogen receptor/AP-1 pathway: Potential origin for the cell-specific estrogen-like effects of antiestrogens. Mol. Endocrinol. 1995, 9, 443-456. [PubMed]

90. Paech, K.; Webb, P.; Kuiper, G.G.; Nilsson, S.; Gustafsson, J.; Kushner, P.J.; Scanlan, T.S. Differential ligand activation of estrogen receptors ER $\alpha$ and ER $\beta$ at AP1 sites. Science 1997, 277, 1508-1510. [CrossRef] [PubMed]

91. Saville, B.; Wormke, M.; Wang, F.; Nguyen, T.; Enmark, E.; Kuiper, G.; Gustafsson, J.A.; Safe, S. Ligand-, cell-, and estrogen receptor subtype $(\alpha / \beta)$-dependent activation at GC-rich (SP1) promoter elements. J. Biol. Chem. 2000, 275, 5379-5387. [CrossRef] [PubMed]

92. Swaneck, G.E.; Alvarez, J.M.; Sufrin, G. Multiple species of estrogen binding sites in the nuclear fraction of the rat prostate. Biochem. Biophys. Res. Commun. 1982, 106, 1441-1447. [CrossRef]

93. Yu, M.; Cates, J.; Leav, I.; Ho, S.M. Heterogeneity of [3H] estradiol binding sites in the rat prostate: Properties and distribution of type I and type II sites. J. Steroid Biochem. 1989, 33, 449-457. [CrossRef]

94. Ekman, P.; Barrack, E.R.; Greene, G.L.; Jensen, E.V.; Walsh, P.C. Estrogen receptors in human prostate: Evidence for multiple binding sites. J. Clin. Endocrinol. Metab. 1983, 57, 166-176. [CrossRef] [PubMed]

95. Donnelly, B.J.; Lakey, W.H.; McBlain, W.A. Estrogen receptor in human benign prostatic hyperplasia. J. Urol. 1983, 130, 183-187. [PubMed]

96. Markaverich, B.M.; Alejandro, M.A. Type II [3H] estradiol binding site antagonists: Inhibition of normal and malignant prostate cell growth and proliferation. Int. J. Oncol. 1998, 12, 1127-1135. [CrossRef] [PubMed]

97. Shoulars, K.; Brown, T.; Alejandro, M.A.; Crowley, J.; Markaverich, B.M. Identification of nuclear type II [(3)H] estradiol binding sites as histone H4. Biochem. Biophys. Res. Commun. 2002, 296, 1083-1090. [CrossRef]

98. Kuiper, G.G.; Enmark, E.; Pelto-Huikko, M.; Nilsson, S.; Gustafsson, J.A. Cloning of a novel receptor expressed in rat prostate and ovary. Proc. Natl. Acad. Sci. USA 1996, 93, 5925-5930. [CrossRef] [PubMed]

99. Mosselman, S.; Polman, J.; Dijkema, R. Er $\beta$ : Identification and characterization of a novel human estrogen receptor. FEBS Lett. 1996, 392, 49-53. [CrossRef]

100. Seitz, G.; Wernert, N. Immunohistochemical estrogen receptor demonstration in the prostate and prostate cancer. Pathol. Res. Pract. 1987, 182, 792-796. [CrossRef]

101. Konishi, N.; Nakaoka, S.; Hiasa, Y.; Kitahori, Y.; Ohshima, M.; Samma, S.; Okajima, E. Immunohistochemical evaluation of estrogen receptor status in benign prostatic hypertrophy and in prostate carcinoma and the relationship to efficacy of endocrine therapy. Oncology 1993, 50, 259-263. [CrossRef] [PubMed]

102. Ehara, H.; Koji, T.; Deguchi, T.; Yoshii, A.; Nakano, M.; Nakane, P.K.; Kawada, Y. Expression of estrogen receptor in diseased human prostate assessed by non-radioactive in situ hybridization and immunohistochemistry. Prostate 1995, 27, 304-313. [CrossRef] [PubMed]

103. Adams, J.Y.; Leav, I.; Lau, K.M.; Ho, S.M.; Pflueger, S.M. Expression of estrogen receptor $\beta$ in the fetal, neonatal, and prepubertal human prostate. Prostate 2002, 52, 69-81. [CrossRef] [PubMed]

104. Chung, L.W. Implications of stromal-epithelial interaction in human prostate cancer growth, progression and differentiation. Semin. Cancer Biol. 1993, 4, 183-192. [PubMed]

105. Farnsworth, W.E. Roles of estrogen and SHBG in prostate physiology. Prostate 1996, 28, 17-23. [CrossRef]

106. Chung, L.W.; Davies, R. Prostate epithelial differentiation is dictated by its surrounding stroma. Mol. Biol. Rep. 1996, 23, 13-19. [CrossRef] [PubMed]

107. Bacher, M.; Rausch, U.; Goebel, H.W.; Polzar, B.; Mannherz, H.G.; Aumuller, G. Stromal and epithelial cells from rat ventral prostate during androgen deprivation and estrogen treatment-Regulation of transcription. Exp. Clin. Endocrinol. 1993, 101, 78-86. [CrossRef] [PubMed]

108. Gupta, C. The role of estrogen receptor, androgen receptor and growth factors in diethylstilbestrol-induced programming of prostate differentiation. Urol. Res. 2000, 28, 223-229. [CrossRef] [PubMed]

109. Marengo, S.R.; Chung, L.W. An orthotopic model for the study of growth factors in the ventral prostate of the rat: Effects of epidermal growth factor and basic fibroblast growth factor. J. Androl. 1994, 15, 277-286. [PubMed]

110. Udayakumar, T.S.; Jeyaraj, D.A.; Rajalakshmi, M.; Sharma, R.S. Culture of prostate epithelial cells of the rhesus monkey on extracellular matrix substrate: Influence of steroids and insulin-like growth factors. J. Endocrinol. 1999, 162, 443-450. [CrossRef] [PubMed] 
111. Torring, N.; Vinter-Jensen, L.; Pedersen, S.B.; Sorensen, F.B.; Flyvbjerg, A.; Nexo, E. Systemic administration of insulin-like growth factor I (IGF-I) causes growth of the rat prostate. J. Urol. 1997, 158, 222-227. [CrossRef] [PubMed]

112. Eddy, E.M.; Washburn, T.F.; Bunch, D.O.; Goulding, E.H.; Gladen, B.C.; Lubahn, D.B.; Korach, K.S. Targeted disruption of the estrogen receptor gene in male mice causes alteration of spermatogenesis and infertility. Endocrinology 1996, 137, 4796-4805. [PubMed]

113. Donaldson, K.M.; Tong, S.Y.; Washburn, T.; Lubahn, D.B.; Eddy, E.M.; Hutson, J.M.; Korach, K.S. Morphometric study of the gubernaculum in male estrogen receptor mutant mice. J. Androl. 1996, 17, 91-95. [PubMed]

114. Bonkhoff, H.; Fixemer, T.; Hunsicker, I.; Remberger, K. Estrogen receptor expression in prostate cancer and premalignant prostatic lesions. Am. J. Pathol. 1999, 155, 641-647. [CrossRef]

115. Leav, I.; Lau, K.M.; Adams, J.Y.; McNeal, J.E.; Taplin, M.E.; Wang, J.; Singh, H.; Ho, S.M. Comparative studies of the estrogen receptors $\beta$ and $\alpha$ and the androgen receptor in normal human prostate glands, dysplasia, and in primary and metastatic carcinoma. Am. J. Pathol. 2001, 159, 79-92. [CrossRef]

116. Royuela, M.; de Miguel, M.P.; Bethencourt, F.R.; Sanchez-Chapado, M.; Fraile, B.; Arenas, M.I.; Paniagua, R. Estrogen receptors $\alpha$ and $\beta$ in the normal, hyperplastic and carcinomatous human prostate. J. Endocrinol. 2001, 168, 447-454. [CrossRef] [PubMed]

117. Bashirelahi, N.; Young, J.D.; Shida, K.; Yamanaka, H.; Ito, Y.; Harada, M. Androgen, estrogen, and progesterone receptors in peripheral and central zones of human prostate with adenocarcinoma. Urology 1983, 21, 530-535. [CrossRef]

118. Bowman, S.P.; Barnes, D.M.; Blacklock, N.J.; Sullivan, P.J. Regional variation of cytosol androgen receptors throughout the diseased human prostate gland. Prostate 1986, 8, 167-180. [CrossRef] [PubMed]

119. Sciarra, F.; Monti, S.; Adamo, M.V.; Palma, E.; Toscano, V.; d’Eramo, G.; di Silverio, F. Regional distribution of epidermal growth factor, testosterone and dihydrotestosterone in benign prostatic hyperplasia tissue. Urol. Res. 1995, 23, 387-390. [CrossRef] [PubMed]

120. Greene, D.R.; Fitzpatrick, J.M.; Scardino, P.T. Anatomy of the prostate and distribution of early prostate cancer. Semin. Surg. Oncol. 1995, 11, 9-22. [CrossRef] [PubMed]

121. McNeal, J.E.; Redwine, E.A.; Freiha, F.S.; Stamey, T.A. Zonal distribution of prostatic adenocarcinoma. Correlation with histologic pattern and direction of spread. Am. J. Surg. Pathol. 1988, 12, 897-906. [CrossRef] [PubMed]

122. Wernert, N.; Gerdes, J.; Loy, V.; Seitz, G.; Scherr, O.; Dhom, G. Investigations of the estrogen (ER-ICA-test) and the progesterone receptor in the prostate and prostatic carcinoma on immunohistochemical basis. Virchows Arch. A Pathol. Anat. Histopathol. 1988, 412, 387-391. [CrossRef] [PubMed]

123. Hobisch, A.; Hittmair, A.; Daxenbichler, G.; Wille, S.; Radmayr, C.; Hobisch-Hagen, P.; Bartsch, G.; Klocker, H.; Culig, Z. Metastatic lesions from prostate cancer do not express oestrogen and progesterone receptors. J. Pathol. 1997, 182, 356-361. [CrossRef]

124. Bodker, A.; Bruun, J.; Balslev, E.; Iversen, H.G.; Meyhoff, H.H.; Andersson, K.E. Estrogen receptors in the human male prostatic urethra and prostate in prostatic cancer and benign prostatic hyperplasia. Scand. J. Urol. Nephrol. 1999, 33, 237-242. [PubMed]

125. Carruba, G.; Pfeffer, U.; Fecarotta, E.; Coviello, D.A.; D’Amato, E.; Lo Castro, M.; Vidali, G.; Castagnetta, L. Estradiol inhibits growth of hormone-nonresponsive PC3 human prostate cancer cells. Cancer Res. 1994, 54, 1190-1193. [PubMed]

126. Castagnetta, L.A.; Miceli, M.D.; Sorci, C.M.; Pfeffer, U.; Farruggio, R.; Oliveri, G.; Calabro, M.; Carruba, G. Growth of LNCAP human prostate cancer cells is stimulated by estradiol via its own receptor. Endocrinology 1995, 136, 2309-2319. [PubMed]

127. Ye, Q.; Chung, L.W.; Cinar, B.; Li, S.; Zhau, H.E. Identification and characterization of estrogen receptor variants in prostate cancer cell lines. J. Steroid Biochem. Mol. Biol. 2000, 75, 21-31. [CrossRef]

128. Latil, A.; Bieche, I.; Vidaud, D.; Lidereau, R.; Berthon, P.; Cussenot, O.; Vidaud, M. Evaluation of androgen, estrogen (ER $\alpha$ and ER $\beta$ ), and progesterone receptor expression in human prostate cancer by real-time quantitative reverse transcription-polymerase chain reaction assays. Cancer Res. 2001, 61, 1919-1926. [PubMed] 
129. Horvath, L.G.; Henshall, S.M.; Lee, C.S.; Head, D.R.; Quinn, D.I.; Makela, S.; Delprado, W.; Golovsky, D.; Brenner, P.C.; O'Neill, G.; et al. Frequent loss of estrogen receptor- $\beta$ expression in prostate cancer. Cancer Res. 2001, 61, 5331-5335. [PubMed]

130. Mak, P.; Leav, I.; Pursell, B.; Bae, D.; Yang, X.; Taglienti, C.A.; Gouvin, L.M.; Sharma, V.M.; Mercurio, A.M. ERbeta impedes prostate cancer EMT by destabilizing HIF- $1 \alpha$ and inhibiting VEGF-mediated snail nuclear localization: Implications for Gleason grading. Cancer Cell 2010, 17, 319-332. [PubMed]

131. Lai, J.S.; Brown, L.G.; True, L.D.; Hawley, S.J.; Etzioni, R.B.; Higano, C.S.; Ho, S.M.; Vessella, R.L.; Corey, E. Metastases of prostate cancer express estrogen receptor- $\beta$. Urology 2004, 64, 814-820. [CrossRef] [PubMed]

132. Yoneda, T. Cellular and molecular mechanisms of breast and prostate cancer metastasis to bone. Eur. J. Cancer 1998, 34, 240-245. [CrossRef]

133. Moore, J.T.; McKee, D.D.; Slentz-Kesler, K.; Moore, L.B.; Jones, S.A.; Horne, E.L.; Su, J.L.; Kliewer, S.A.; Lehmann, J.M.; Willson, T.M. Cloning and characterization of human estrogen receptor $\beta$ isoforms. Biochem. Biophys. Res. Commun. 1998, 247, 75-78. [CrossRef] [PubMed]

134. Leung, Y.K.; Mak, P.; Hassan, S.; Ho, S.M. Estrogen receptor (ER)- $\beta$ isoforms: A key to understanding er-beta signaling. Proc. Natl. Acad. Sci. USA 2006, 103, 13162-13167. [CrossRef] [PubMed]

135. Leung, Y.K.; Lam, H.M.; Wu, S.; Song, D.; Levin, L.; Cheng, L.; Wu, C.L.; Ho, S.M. Estrogen receptor $\beta 2$ and $\beta 5$ are associated with poor prognosis in prostate cancer, and promote cancer cell migration and invasion. Endocr. Relat. Cancer 2010, 17, 675-689. [CrossRef] [PubMed]

136. Cotrim, C.Z.; Fabris, V.; Doria, M.L.; Lindberg, K.; Gustafsson, J.A.; Amado, F.; Lanari, C.; Helguero, L.A. Estrogen receptor beta growth-inhibitory effects are repressed through activation of MAPK and PI3K signalling in mammary epithelial and breast cancer cells. Oncogene 2013, 32, 2390-2402. [CrossRef] [PubMed]

137. Zhao, C.; Matthews, J.; Tujague, M.; Wan, J.; Strom, A.; Toresson, G.; Lam, E.W.; Cheng, G.; Gustafsson, J.A.; Dahlman-Wright, K. Estrogen receptor $\beta 2$ negatively regulates the transactivation of estrogen receptor $\alpha$ in human breast cancer cells. Cancer Res. 2007, 67, 3955-3962. [CrossRef] [PubMed]

138. Greene, G.L.; Gilna, P.; Waterfield, M.; Baker, A.; Hort, Y.; Shine, J. Sequence and expression of human estrogen receptor complementary DNA. Science 1986, 231, 1150-1154. [CrossRef] [PubMed]

139. Green, S.; Walter, P.; Kumar, V.; Krust, A.; Bornert, J.M.; Argos, P.; Chambon, P. Human oestrogen receptor cDNA: Sequence, expression and homology to V-ERB-A. Nature 1986, 320, 134-139. [CrossRef] [PubMed]

140. Enmark, E.; Kainu, T.; Pelto-Huikko, M.; Gustafsson, J.A. Identification of a novel member of the nuclear receptor superfamily which is closely related to REV-ERBA. Biochem. Biophys. Res. Commun. 1994, 204, 49-56. [CrossRef] [PubMed]

141. Tremblay, G.B.; Tremblay, A.; Copeland, N.G.; Gilbert, D.J.; Jenkins, N.A.; Labrie, F.; Giguere, V. Cloning, chromosomal localization, and functional analysis of the murine estrogen receptor $\beta$. Mol. Endocrinol. 1997, 11, 353-365. [PubMed]

142. O'Lone, R.; Frith, M.C.; Karlsson, E.K.; Hansen, U. Genomic targets of nuclear estrogen receptors. Mol. Endocrinol. 2004, 18, 1859-1875. [CrossRef] [PubMed]

143. Kuiper, G.G.; Carlsson, B.; Grandien, K.; Enmark, E.; Haggblad, J.; Nilsson, S.; Gustafsson, J.A. Comparison of the ligand binding specificity and transcript tissue distribution of estrogen receptors $\alpha$ and $\beta$. Endocrinology 1997, 138, 863-870. [CrossRef] [PubMed]

144. Pace, P.; Taylor, J.; Suntharalingam, S.; Coombes, R.C.; Ali, S. Human estrogen receptor $\beta$ binds DNA in a manner similar to and dimerizes with estrogen receptor $\alpha$. J. Biol. Chem. 1997, 272, 25832-25838. [CrossRef] [PubMed]

145. Pettersson, K.; Grandien, K.; Kuiper, G.G.; Gustafsson, J.A. Mouse estrogen receptor beta forms estrogen response element-binding heterodimers with estrogen receptor $\alpha$. Mol. Endocrinol. 1997, 11, 1486-1496. [PubMed]

146. Ogawa, S.; Inoue, S.; Watanabe, T.; Hiroi, H.; Orimo, A.; Hosoi, T.; Ouchi, Y.; Muramatsu, M. The complete primary structure of human estrogen receptor $\beta($ HER $\beta)$ and its heterodimerization with ER $\alpha$ in vivo and in vitro. Biochem. Biophys. Res. Commun. 1998, 243, 122-126. [CrossRef] [PubMed]

147. Kushner, P.J.; Agard, D.A.; Greene, G.L.; Scanlan, T.S.; Shiau, A.K.; Uht, R.M.; Webb, P. Estrogen receptor pathways to AP-1. J. Steroid Biochem. Mol. Biol. 2000, 74, 311-317. [CrossRef]

148. Zhao, C.; Dahlman-Wright, K.; Gustafsson, J.A. Estrogen signaling via estrogen receptor $\beta$. J. Biol. Chem. 2010, 285, 39575-39579. [CrossRef] [PubMed] 
149. Shiau, A.K.; Barstad, D.; Loria, P.M.; Cheng, L.; Kushner, P.J.; Agard, D.A.; Greene, G.L. The structural basis of estrogen receptor/coactivator recognition and the antagonism of this interaction by tamoxifen. Cell 1998, 95, 927-937. [CrossRef]

150. Pike, A.C.; Brzozowski, A.M.; Hubbard, R.E.; Bonn, T.; Thorsell, A.G.; Engstrom, O.; Ljunggren, J.; Gustafsson, J.A.; Carlquist, M. Structure of the ligand-binding domain of oestrogen receptor $\beta$ in the presence of a partial agonist and a full antagonist. EMBO J. 1999, 18, 4608-4618. [CrossRef] [PubMed]

151. Brzozowski, A.M.; Pike, A.C.; Dauter, Z.; Hubbard, R.E.; Bonn, T.; Engstrom, O.; Ohman, L.; Greene, G.L.; Gustafsson, J.A.; Carlquist, M. Molecular basis of agonism and antagonism in the oestrogen receptor. Nature 1997, 389, 753-758. [CrossRef] [PubMed]

152. Kato, S.; Endoh, H.; Masuhiro, Y.; Kitamoto, T.; Uchiyama, S.; Sasaki, H.; Masushige, S.; Gotoh, Y.; Nishida, E.; Kawashima, H.; et al. Activation of the estrogen receptor through phosphorylation by mitogen-activated protein kinase. Science 1995, 270, 1491-1494. [CrossRef] [PubMed]

153. Bunone, G.; Briand, P.A.; Miksicek, R.J.; Picard, D. Activation of the unliganded estrogen receptor by EGF involves the MAP kinase pathway and direct phosphorylation. EMBO J. 1996, 15, 2174-2183. [PubMed]

154. Tremblay, A.; Tremblay, G.B.; Labrie, F.; Giguere, V. Ligand-independent recruitment of SRC-1 to estrogen receptor $\beta$ through phosphorylation of activation function AF-1. Mol. Cell 1999, 3, 513-519. [CrossRef]

155. Webb, P.; Nguyen, P.; Shinsako, J.; Anderson, C.; Feng, W.; Nguyen, M.P.; Chen, D.; Huang, S.M.; Subramanian, S.; McKinerney, E.; et al. Estrogen receptor activation function 1 works by binding P160 coactivator proteins. Mol. Endocrinol. 1998, 12, 1605-1618. [CrossRef] [PubMed]

156. Gaub, M.P.; Bellard, M.; Scheuer, I.; Chambon, P.; Sassone-Corsi, P. Activation of the ovalbumin gene by the estrogen receptor involves the FOS-JUN complex. Cell 1990, 63, 1267-1276. [CrossRef]

157. Umayahara, Y.; Kawamori, R.; Watada, H.; Imano, E.; Iwama, N.; Morishima, T.; Yamasaki, Y.; Kajimoto, Y.; Kamada, T. Estrogen regulation of the insulin-like growth factor I gene transcription involves an AP-1 enhancer. J. Biol. Chem. 1994, 269, 16433-16442. [PubMed]

158. Webb, P.; Nguyen, P.; Valentine, C.; Lopez, G.N.; Kwok, G.R.; McInerney, E.; Katzenellenbogen, B.S.; Enmark, E.; Gustafsson, J.A.; Nilsson, S.; et al. The estrogen receptor enhances AP-1 activity by two distinct mechanisms with different requirements for receptor transactivation functions. Mol. Endocrinol. 1999, 13, 1672-1685. [CrossRef] [PubMed]

159. Jackson, T.A.; Richer, J.K.; Bain, D.L.; Takimoto, G.S.; Tung, L.; Horwitz, K.B. The partial agonist activity of antagonist-occupied steroid receptors is controlled by a novel hinge domain-binding coactivator 17/SPA and the corepressors N-COR or SMRT. Mol. Endocrinol. 1997, 11, 693-705. [CrossRef] [PubMed]

160. Lavinsky, R.M.; Jepsen, K.; Heinzel, T.; Torchia, J.; Mullen, T.M.; Schiff, R.; Del-Rio, A.L.; Ricote, M.; Ngo, S.; Gemsch, J.; et al. Diverse signaling pathways modulate nuclear receptor recruitment of N-COR and SMRT complexes. Proc. Natl. Acad. Sci. USA 1998, 95, 2920-2925. [CrossRef] [PubMed]

161. Montano, M.M.; Katzenellenbogen, B.S. The quinone reductase gene: A unique estrogen receptor-regulated gene that is activated by antiestrogens. Proc. Natl. Acad. Sci. USA 1997, 94, 2581-2586. [CrossRef] [PubMed]

162. Montano, M.M.; Jaiswal, A.K.; Katzenellenbogen, B.S. Transcriptional regulation of the human quinone reductase gene by antiestrogen-liganded estrogen receptor- $\alpha$ and estrogen receptor- $\beta$. J. Biol. Chem. 1998, 273, 25443-25449. [CrossRef] [PubMed]

163. Piette, J.; Hirai, S.; Yaniv, M. Constitutive synthesis of activator protein 1 transcription factor after viral transformation of mouse fibroblasts. Proc. Natl. Acad. Sci. USA 1988, 85, 3401-3405. [CrossRef] [PubMed]

164. Nguyen, T.; Pickett, C.B. Regulation of rat glutathione S-transferase ya subunit gene expression. DNA-protein interaction at the antioxidant responsive element. J. Biol. Chem. 1992, 267, 13535-13539. [PubMed]

165. Favreau, L.V.; Pickett, C.B. Transcriptional regulation of the rat NAD $(\mathrm{P}) \mathrm{H}$ :Quinone reductase gene. Characterization of a DNA-protein interaction at the antioxidant responsive element and induction by 12-O-tetradecanoylphorbol 13-acetate. J. Biol. Chem. 1993, 268, 19875-19881. [PubMed]

166. Montano, M.M.; Wittmann, B.M.; Bianco, N.R. Identification and characterization of a novel factor that regulates quinone reductase gene transcriptional activity. J. Biol. Chem. 2000, 275, 34306-34313. [CrossRef] [PubMed]

167. Krishnamurthy, N.; Ngam, C.R.; Berdis, A.J.; Montano, M.M. The exonuclease activity of HPMC2 is required for transcriptional regulation of the $Q R$ gene and repair of estrogen-induced abasic sites. Oncogene 2011, 30, 4731-4739. [CrossRef] [PubMed] 
168. Qiu, X.; Forman, H.J.; Schonthal, A.H.; Cadenas, E. Induction of p21 mediated by reactive oxygen species formed during the metabolism of aziridinylbenzoquinones by hct116 cells. J. Biol. Chem. 1996, 271, 31915-31921. [CrossRef] [PubMed]

169. Lau, K.M.; LaSpina, M.; Long, J.; Ho, S.M. Expression of estrogen receptor (ER)- $\alpha$ and ER- $\beta$ in normal and malignant prostatic epithelial cells: Regulation by methylation and involvement in growth regulation. Cancer Res. 2000, 60, 3175-3182. [PubMed]

170. Leung, Y.K.; Gao, Y.; Lau, K.M.; Zhang, X.; Ho, S.M. Ici 182,780-regulated gene expression in du145 prostate cancer cells is mediated by estrogen receptor- $\beta / \mathrm{NF}$ KB crosstalk. Neoplasia 2006, 8, 242-249. [CrossRef] [PubMed]

171. Lubahn, D.B.; Moyer, J.S.; Golding, T.S.; Couse, J.F.; Korach, K.S.; Smithies, O. Alteration of reproductive function but not prenatal sexual development after insertional disruption of the mouse estrogen receptor gene. Proc. Natl. Acad. Sci. USA 1993, 90, 11162-11166. [CrossRef] [PubMed]

172. Dupont, S.; Krust, A.; Gansmuller, A.; Dierich, A.; Chambon, P.; Mark, M. Effect of single and compound knockouts of estrogen receptors $\alpha(\operatorname{Er} \alpha)$ and $\beta(\operatorname{Er} \beta)$ on mouse reproductive phenotypes. Development 2000, 127, 4277-4291. [PubMed]

173. Krege, J.H.; Hodgin, J.B.; Couse, J.F.; Enmark, E.; Warner, M.; Mahler, J.F.; Sar, M.; Korach, K.S.; Gustafsson, J.A.; Smithies, O. Generation and reproductive phenotypes of mice lacking estrogen receptor $\beta$. Proc. Natl. Acad. Sci. USA 1998, 95, 15677-15682. [CrossRef] [PubMed]

174. Couse, J.F.; Hewitt, S.C.; Bunch, D.O.; Sar, M.; Walker, V.R.; Davis, B.J.; Korach, K.S. Postnatal sex reversal of the ovaries in mice lacking estrogen receptors $\alpha$ and $\beta$. Science 1999, 286, 2328-2331. [CrossRef] [PubMed]

175. Couse, J.F.; Korach, K.S. Estrogen receptor null mice: What have we learned and where will they lead us? Endocr. Rev. 1999, 20, 358-417. [CrossRef] [PubMed]

176. Prins, G.S.; Korach, K.S. The role of estrogens and estrogen receptors in normal prostate growth and disease. Steroids 2008, 73, 233-244. [CrossRef] [PubMed]

177. Byar, D.P. Proceedings: The veterans administration cooperative urological research group's studies of cancer of the prostate. Cancer 1973, 32, 1126-1130. [CrossRef]

178. Pitts, W.R., Jr. Diethylstilbesterol: First-line hormonal therapy for prostate cancer? Urology 1999, 53, 660-661. [PubMed]

179. Seidenfeld, J.; Samson, D.J.; Aronson, N.; Albertson, P.C.; Bayoumi, A.M.; Bennett, C.; Brown, A.; Garber, A.; Gere, M.; Hasselblad, V.; et al. Relative effectiveness and cost-effectiveness of methods of androgen suppression in the treatment of advanced prostate cancer. Evid. Rep. Technol. Assess. 1999, 4, 1-246.

180. Kitahara, S.; Umeda, H.; Yano, M.; Koga, F.; Sumi, S.; Moriguchi, H.; Hosoya, Y.; Honda, M.; Yoshida, K. Effects of intravenous administration of high dose-diethylstilbestrol diphosphate on serum hormonal levels in patients with hormone-refractory prostate cancer. Endocr. J. 1999, 46, 659-664. [CrossRef] [PubMed]

181. Bayoumi, A.M.; Brown, A.D.; Garber, A.M. Cost-effectiveness of androgen suppression therapies in advanced prostate cancer. J. Natl. Cancer Inst. 2000, 92, 1731-1739. [CrossRef] [PubMed]

182. Paulson, D.F. Management of metastatic prostatic cancer. Urology 1985, 25, 49-52. [PubMed]

183. Brehmer, B.; Marquardt, H.; Madsen, P.O. Growth and hormonal response of cells derived from carcinoma and hyperplasia of the prostate in monolayer cell culture. A possible in vitro model for clinical chemotherapy. J. Urol. 1972, 108, 890-896. [PubMed]

184. Hartley-Asp, B.; Deinum, J.; Wallin, M. Diethylstilbestrol induces metaphase arrest and inhibits microtubule assembly. Mutat. Res. 1985, 143, 231-235. [CrossRef]

185. Robertson, C.N.; Roberson, K.M.; Padilla, G.M.; O’Brien, E.T.; Cook, J.M.; Kim, C.S.; Fine, R.L. Induction of apoptosis by diethylstilbestrol in hormone-insensitive prostate cancer cells. J. Natl. Cancer Inst. 1996, 88, 908-917. [CrossRef] [PubMed]

186. Trapman, J.; Ris-Stalpers, C.; van der Korput, J.A.; Kuiper, G.G.; Faber, P.W.; Romijn, J.C.; Mulder, E.; Brinkmann, A.O. The androgen receptor: Functional structure and expression in transplanted human prostate tumors and prostate tumor cell lines. J. Steroid Biochem. Mol. Biol. 1990, 37, 837-842. [CrossRef]

187. Veldscholte, J.; Voorhorst-Ogink, M.M.; Bolt-de Vries, J.; van Rooij, H.C.; Trapman, J.; Mulder, E. Unusual specificity of the androgen receptor in the human prostate tumor cell line LNCAP: High affinity for progestagenic and estrogenic steroids. Biochim. Biophys. Acta 1990, 1052, 187-194. [CrossRef]

188. Noble, R.L. Production of NB rat carcinoma of the dorsal prostate and response of estrogen-dependent transplants to sex hormones and tamoxifen. Cancer Res. 1980, 40, 3547-3550. [PubMed] 
189. Glick, J.H.; Wein, A.; Padavic, K.; Negendank, W.; Harris, D.; Brodovsky, H. Phase II trial of tamoxifen in metastatic carcinoma of the prostate. Cancer 1982, 49, 1367-1372. [CrossRef]

190. Spremulli, E.; DeSimone, P.; Durant, J. A phase II study nolvadex: Tamoxifen citrate in the treatment of advanced prostatic adenocarcinoma. Am. J. Clin. Oncol. 1982, 5, 149-153. [CrossRef] [PubMed]

191. Rayter, Z.; Gazet, J.C.; Shephed, J.; Trott, P.; Svensson, W.; A'Hern, R. Effects of tamoxifen on uterus. Lancet 1994, 344, 623-624.

192. Eells, T.P.; Alpern, H.D.; Grzywacz, C.; MacMillan, R.W.; Olson, J.E. The effect of tamoxifen on cervical squamous maturation in papanicolaou stained cervical smears of post-menopausal women. Cytopathology 1990, 1, 263-268. [CrossRef] [PubMed]

193. Kedar, R.P.; Bourne, T.H.; Powles, T.J.; Collins, W.P.; Ashley, S.E.; Cosgrove, D.O.; Campbell, S. Effects of tamoxifen on uterus and ovaries of postmenopausal women in a randomised breast cancer prevention trial. Lancet 1994, 343, 1318-1321. [CrossRef]

194. Horton, J.; Rosenbaum, C.; Cummings, F.J. Tamoxifen in advanced prostate cancer: An ECOG pilot study. Prostate 1988, 12, 173-177. [CrossRef] [PubMed]

195. Wakeling, A.E.; Dukes, M.; Bowler, J. A potent specific pure antiestrogen with clinical potential. Cancer Res. 1991, 51, 3867-3873. [PubMed]

196. Osborne, C.K.; Coronado-Heinsohn, E.B.; Hilsenbeck, S.G.; McCue, B.L.; Wakeling, A.E.; McClelland, R.A.; Manning, D.L.; Nicholson, R.I. Comparison of the effects of a pure steroidal antiestrogen with those of tamoxifen in a model of human breast cancer. J. Natl. Cancer Inst. 1995, 87, 746-750. [CrossRef] [PubMed]

197. Bhattacharyya, R.S.; Krishnan, A.V.; Swami, S.; Feldman, D. Fulvestrant (ICI 182,780) down-regulates androgen receptor expression and diminishes androgenic responses in LNCAP human prostate cancer cells. Mol. Cancer Ther. 2006, 5, 1539-1549. [CrossRef] [PubMed]

198. Leung, Y.K.; Chan, Q.K.; Ng, C.F.; Ma, F.M.; Tse, H.M.; To, K.F.; Maranchie, J.; Ho, S.M.; Lau, K.M. Hsa-miRNA-765 as a key mediator for inhibiting growth, migration and invasion in fulvestrant-treated prostate cancer. PLoS ONE 2014, 9, e98037. [CrossRef] [PubMed]

199. Chadha, M.K.; Ashraf, U.; Lawrence, D.; Tian, L.; Levine, E.; Silliman, C.; Escott, P.; Payne, V.; Trump, D.L. Phase II study of fulvestrant (faslodex) in castration resistant prostate cancer. Prostate 2008, 68, 1461-1466. [CrossRef] [PubMed]

200. Gasent Blesa, J.M.; Alberola Candel, V.; Giner Marco, V.; Giner-Bosch, V.; Provencio Pulla, M.; Laforga Canales, J.B. Experience with fulvestrant acetate in castration-resistant prostate cancer patients. Ann. Oncol. 2010, 21, 1131-1132. [CrossRef] [PubMed]

201. Di Leo, A.; Jerusalem, G.; Petruzelka, L.; Torres, R.; Bondarenko, I.N.; Khasanov, R.; Verhoeven, D.; Pedrini, J.L.; Smirnova, I.; Lichinitser, M.R.; et al. Final overall survival: Fulvestrant 500 mg vs. $250 \mathrm{mg}$ in the randomized CONFIRM trial. J. Natl. Cancer Inst. 2014, 106, 349-351.

202. Losel, R.; Wehling, M. Nongenomic actions of steroid hormones. Nat. Rev. Mol. Cell Biol. 2003, 4, 46-56. [CrossRef] [PubMed]

203. Moriarty, K.; Kim, K.H.; Bender, J.R. Minireview: Estrogen receptor-mediated rapid signaling. Endocrinology 2006, 147, 5557-5563. [CrossRef] [PubMed]

204. Pietras, R.J.; Szego, C.M. Cell membrane estrogen receptors resurface. Nat. Med. 1999, 5, 1330. [CrossRef] [PubMed]

205. Kim, H.P.; Lee, J.Y.; Jeong, J.K.; Bae, S.W.; Lee, H.K.; Jo, I. Nongenomic stimulation of nitric oxide release by estrogen is mediated by estrogen receptor $\alpha$ localized in caveolae. Biochem. Biophys. Res. Commun. 1999, 263, 257-262. [CrossRef] [PubMed]

206. Haynes, M.P.; Russell, K.S.; Bender, J.R. Molecular mechanisms of estrogen actions on the vasculature. J. Nucl. Cardiol. 2000, 7, 500-508. [CrossRef] [PubMed]

207. Stefano, G.B.; Cadet, P.; Breton, C.; Goumon, Y.; Prevot, V.; Dessaint, J.P.; Beauvillain, J.C.; Roumier, A.S.; Welters, I.; Salzet, M. Estradiol-stimulated nitric oxide release in human granulocytes is dependent on intracellular calcium transients: Evidence of a cell surface estrogen receptor. Blood 2000, 95, 3951-3958. [PubMed]

208. Doolan, C.M.; Harvey, B.J. A G $\alpha$ s protein-coupled membrane receptor, distinct from the classical oestrogen receptor, transduces rapid effects of oestradiol on [Ca2+]i in female rat distal colon. Mol. Cell. Endocrinol. 2003, 199, 87-103. [CrossRef] 
209. Pedram, A.; Razandi, M.; Levin, E.R. Nature of functional estrogen receptors at the plasma membrane. Mol. Endocrinol. 2006, 20, 1996-2009. [CrossRef] [PubMed]

210. Russell, K.S.; Haynes, M.P.; Sinha, D.; Clerisme, E.; Bender, J.R. Human vascular endothelial cells contain membrane binding sites for estradiol, which mediate rapid intracellular signaling. Proc. Natl. Acad. Sci. USA 2000, 97, 5930-5935. [CrossRef] [PubMed]

211. Wyckoff, M.H.; Chambliss, K.L.; Mineo, C.; Yuhanna, I.S.; Mendelsohn, M.E.; Mumby, S.M.; Shaul, P.W. Plasma membrane estrogen receptors are coupled to endothelial nitric-oxide synthase through $\mathrm{G} \alpha(\mathrm{I})$. J. Biol. Chem. 2001, 276, 27071-27076. [CrossRef] [PubMed]

212. Wang, Z.; Zhang, X.; Shen, P.; Loggie, B.W.; Chang, Y.; Deuel, T.F. A variant of estrogen receptor- $\alpha$, HER- $\alpha 36$ : Transduction of estrogen- and antiestrogen-dependent membrane-initiated mitogenic signaling. Proc. Natl. Acad. Sci. USA 2006, 103, 9063-9068. [CrossRef] [PubMed]

213. Chambliss, K.L.; Yuhanna, I.S.; Anderson, R.G.; Mendelsohn, M.E.; Shaul, P.W. ER $\beta$ has nongenomic action in caveolae. Mol. Endocrinol. 2002, 16, 938-946. [CrossRef] [PubMed]

214. Filardo, E.J.; Quinn, J.A.; Bland, K.I.; Frackelton, A.R., Jr. Estrogen-induced activation of ERK-1 and ERK-2 requires the g protein-coupled receptor homolog, GPR30, and occurs via trans-activation of the epidermal growth factor receptor through release of HB-EGF. Mol. Endocrinol. 2000, 14, 1649-1660. [CrossRef] [PubMed]

215. Revankar, C.M.; Cimino, D.F.; Sklar, L.A.; Arterburn, J.B.; Prossnitz, E.R. A transmembrane intracellular estrogen receptor mediates rapid cell signaling. Science 2005, 307, 1625-1630. [CrossRef] [PubMed]

216. Thomas, P.; Pang, Y.; Filardo, E.J.; Dong, J. Identity of an estrogen membrane receptor coupled to a G protein in human breast cancer cells. Endocrinology 2005, 146, 624-632. [CrossRef] [PubMed]

217. Prossnitz, E.R.; Arterburn, J.B. International union of basic and clinical pharmacology. Xcvii. G protein-coupled estrogen receptor and its pharmacologic modulators. Pharmacol. Rev. 2015, 67, 505-540. [CrossRef] [PubMed]

218. Rosenbaum, D.M.; Rasmussen, S.G.; Kobilka, B.K. The structure and function of G-protein-coupled receptors. Nature 2009, 459, 356-363. [CrossRef] [PubMed]

219. Filardo, E.J.; Thomas, P. Gpr30: A seven-transmembrane-spanning estrogen receptor that triggers EGF release. Trends Endocrinol. Metab. 2005, 16, 362-367. [CrossRef] [PubMed]

220. Vivacqua, A.; Bonofiglio, D.; Albanito, L.; Madeo, A.; Rago, V.; Carpino, A.; Musti, A.M.; Picard, D.; Ando, S.; Maggiolini, M. 17 $\beta$-estradiol, genistein, and 4-hydroxytamoxifen induce the proliferation of thyroid cancer cells through the G protein-coupled receptor GPR30. Mol. Pharmacol. 2006, 70, 1414-1423. [CrossRef] [PubMed]

221. Vivacqua, A.; Bonofiglio, D.; Recchia, A.G.; Musti, A.M.; Picard, D.; Ando, S.; Maggiolini, M. The G protein-coupled receptor GPR30 mediates the proliferative effects induced by $17 \beta$-estradiol and hydroxytamoxifen in endometrial cancer cells. Mol. Endocrinol. 2006, 20, 631-646. [CrossRef] [PubMed]

222. Albanito, L.; Madeo, A.; Lappano, R.; Vivacqua, A.; Rago, V.; Carpino, A.; Oprea, T.I.; Prossnitz, E.R.; Musti, A.M.; Ando, S.; et al. G protein-coupled receptor 30 (GPR30) mediates gene expression changes and growth response to $17 \beta$-estradiol and selective GPR30 ligand G-1 in ovarian cancer cells. Cancer Res. 2007, 67, 1859-1866. [CrossRef] [PubMed]

223. Teng, J.; Wang, Z.Y.; Prossnitz, E.R.; Bjorling, D.E. The g protein-coupled receptor GPR30 inhibits human urothelial cell proliferation. Endocrinology 2008, 149, 4024-4034. [CrossRef] [PubMed]

224. Chan, Q.K.; Lam, H.M.; Ng, C.F.; Lee, A.Y.; Chan, E.S.; Ng, H.K.; Ho, S.M.; Lau, K.M. Activation of GPR30 inhibits the growth of prostate cancer cells through sustained activation of erk1/2, c-jun/c-fos-dependent upregulation of p21, and induction of G2 cell-cycle arrest. Cell Death Differ. 2010, 17, 1511-1523. [CrossRef] [PubMed]

225. Liu, S.; Le May, C.; Wong, W.P.; Ward, R.D.; Clegg, D.J.; Marcelli, M.; Korach, K.S.; Mauvais-Jarvis, F. Importance of extranuclear estrogen receptor- $\alpha$ and membrane $G$ protein-coupled estrogen receptor in pancreatic islet survival. Diabetes 2009, 58, 2292-2302. [CrossRef] [PubMed]

226. Prossnitz, E.R.; Hathaway, H.J. What have we learned about GPER function in physiology and disease from knockout mice? J. Steroid Biochem. Mol. Biol. 2015, 153, 114-126. [CrossRef] [PubMed]

227. Filardo, E.J.; Quinn, J.A.; Frackelton, A.R., Jr.; Bland, K.I. Estrogen action via the G protein-coupled receptor, GPR30: Stimulation of adenylyl cyclase and CAMP-mediated attenuation of the epidermal growth factor receptor-to-MAPK signaling axis. Mol. Endocrinol. 2002, 16, 70-84. [CrossRef] [PubMed] 
228. Bologa, C.G.; Revankar, C.M.; Young, S.M.; Edwards, B.S.; Arterburn, J.B.; Kiselyov, A.S.; Parker, M.A.; Tkachenko, S.E.; Savchuck, N.P.; Sklar, L.A.; et al. Virtual and biomolecular screening converge on a selective agonist for GPR30. Nat. Chem. Biol. 2006, 2, 207-212. [CrossRef] [PubMed]

229. Vanaja, D.K.; Cheville, J.C.; Iturria, S.J.; Young, C.Y. Transcriptional silencing of zinc finger protein 185 identified by expression profiling is associated with prostate cancer progression. Cancer Res. 2003, 63, 3877-3882. [PubMed]

230. Varambally, S.; Yu, J.; Laxman, B.; Rhodes, D.R.; Mehra, R.; Tomlins, S.A.; Shah, R.B.; Chandran, U.; Monzon, F.A.; Becich, M.J.; et al. Integrative genomic and proteomic analysis of prostate cancer reveals signatures of metastatic progression. Cancer Cell 2005, 8, 393-406. [CrossRef] [PubMed]

231. Lam, H.M.; Ouyang, B.; Chen, J.; Ying, J.; Wang, J.; Wu, C.L.; Jia, L.; Medvedovic, M.; Vessella, R.L.; Ho, S.M. Targeting GPR30 with G-1: A new therapeutic target for castration-resistant prostate cancer. Endocr. Relat. Cancer 2014, 21, 903-914. [CrossRef] [PubMed]

232. Adachi, T.; Kar, S.; Wang, M.; Carr, B.I. Transient and sustained ERK phosphorylation and nuclear translocation in growth control. J. Cell. Physiol. 2002, 192, 151-159. [CrossRef] [PubMed]

233. Chen, J.R.; Plotkin, L.I.; Aguirre, J.I.; Han, L.; Jilka, R.L.; Kousteni, S.; Bellido, T.; Manolagas, S.C. Transient versus sustained phosphorylation and nuclear accumulation of ERKS underlie anti-versus pro-apoptotic effects of estrogens. J. Biol. Chem. 2005, 280, 4632-4638. [CrossRef] [PubMed]

234. Pandey, D.P.; Lappano, R.; Albanito, L.; Madeo, A.; Maggiolini, M.; Picard, D. Estrogenic GPR30 signalling induces proliferation and migration of breast cancer cells through CTGF. EMBO J. 2009, 28, 523-532. [CrossRef] [PubMed]

235. Filardo, E.J.; Graeber, C.T.; Quinn, J.A.; Resnick, M.B.; Giri, D.; DeLellis, R.A.; Steinhoff, M.M.; Sabo, E. Distribution of GPR30, a seven membrane-spanning estrogen receptor, in primary breast cancer and its association with clinicopathologic determinants of tumor progression. Clin. Cancer Res. 2006, 12, 6359-6366. [CrossRef] [PubMed]

236. Henic, E.; Noskova, V.; Hoyer-Hansen, G.; Hansson, S.; Casslen, B. Estradiol attenuates EGF-induced rapid UPAR mobilization and cell migration via the g-protein-coupled receptor 30 in ovarian cancer cells. Int. J. Gynecol. Cancer 2009, 19, 214-222. [CrossRef] [PubMed]

237. Kang, L.; Zhang, X.; Xie, Y.; Tu, Y.; Wang, D.; Liu, Z.; Wang, Z.Y. Involvement of estrogen receptor variant ER- $\alpha 36$, not GPR30, in nongenomic estrogen signaling. Mol. Endocrinol. 2010, 24, 709-721. [CrossRef] [PubMed]

(C) 2016 by the authors; licensee MDPI, Basel, Switzerland. This article is an open access article distributed under the terms and conditions of the Creative Commons Attribution (CC-BY) license (http://creativecommons.org/licenses/by/4.0/). 